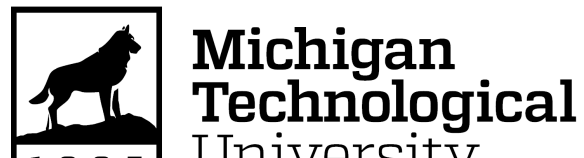 1 в 8 5 University
}

\section{Michigan Technological University \\ Digital Commons @ Michigan Tech}

Department of Geological and Mining

Engineering and Sciences Publications

Department of Geological and Mining

Engineering and Sciences

5-10-1988

\section{Direct rate measurements of eruption plumes at Augustine volcano: A problem of scaling and uncontrolled variables}

\author{
William I. Rose \\ Michigan Technological University \\ Grant Heiken \\ Los Alamos National Laboratory \\ Kenneth Wohletz \\ Los Alamos National Laboratory \\ Dean Eppler \\ Los Alamos National Laboratory \\ Sumner Barr \\ Los Alamos National Laboratory
}

See next page for additional authors

Follow this and additional works at: https://digitalcommons.mtu.edu/geo-fp

Part of the Geology Commons, Mining Engineering Commons, and the Other Engineering Commons

\section{Recommended Citation}

Rose, W. I., Heiken, G., Wohletz, K., Eppler, D., Barr, S., Miller, T., Chuan, R. L., \& Symonds, R. B. (1988). Direct rate measurements of eruption plumes at Augustine volcano: A problem of scaling and uncontrolled variables. Journal of Geophysical Research, 93(B5), 4485-4499. http://dx.doi.org/10.1029/ JB093iB05p04485

Retrieved from: https://digitalcommons.mtu.edu/geo-fp/117

Follow this and additional works at: https://digitalcommons.mtu.edu/geo-fp

Part of the Geology Commons, Mining Engineering Commons, and the Other Engineering Commons 


\section{Authors}

William I. Rose, Grant Heiken, Kenneth Wohletz, Dean Eppler, Sumner Barr, Theresa Miller, Raymond L. Chuan, and R. B. Symonds 


\title{
DIRECT RATE MEASUREMENTS OF ERUPTION PLUMES AT AUGUSTINE VOLCANO: A PROBLEM OF SCALING AND UNCONTROLLED VARIABLES
}

\author{
William I. Rose ${ }^{1}$, Grant Heiken ${ }^{2}$, Kenneth Wohletz ${ }^{2}$, Dean Eppler ${ }^{2}$, Sumner Barr ${ }^{2}$,
} Theresa Miller ${ }^{3}$, Raymond L. Chuan ${ }^{4}$, and Robert B. Symonds 1

\begin{abstract}
The March-April 1986 eruption of Augustine Volcano, Alaska, provided an opportunity to directly measure the flux of gas, aerosol, and ash particles during explosive eruption. Most previous direct measurements of volcanic emission rates are on plumes from fuming volcanoes or on very small eruption clouds. Direct measurements during explosive activity are needed to understand the scale relationships between passive degassing or small eruption plumes and highly explosive events. Conditions on April 3, 1986 were ideal: high
\end{abstract} winds, clear visibility, moderate activity. Three measurements were made: 1) an airborne correlation spectrometer (Cospec) provided mass flux rates of $\mathrm{SO}_{2} ; 2$ ) treated filter samples chemically characterized the plume and 3) a quartz crystal microcascade impactor provided particle size distribution. Atmospheric conditions on April 3 caused the development of a lee wave plume, which allowed us to constrain a model of plume dispersion leading to a forecast map of concentrations of $\mathrm{SO}_{2}$ at greater distances from the vent. On April 3, 1986, the emission rate of $\mathrm{SO}_{2}$ at Augustine was $24,000 \mathrm{t} / \mathrm{d}$, one of the largest direct volcanic rate measurements yet recorded with a Cospec. The results, coupled with analytical results from samples simultaneously collected on filters, allow us to estimate $\mathrm{HCl}$ emissions at $10,000 \mathrm{t} / \mathrm{d}$ and ash eruption rate at $1.5 \times 10^{6} \mathrm{t} / \mathrm{d}$. Based on other data, this ash eruption rate is about $1 / 50$ of the maximum rate during the March-April activity. Filter samples show that the gas:aerosol proportions for sulfur and chlorine are about $10: 1$ and $4: 1$, respectively. By contrast, measurements of Augustine's plume, together with ground-based gas sampling in July 1986 when the volcano was in a posteruptive fuming state, are $380 \mathrm{t} / \mathrm{d} \mathrm{SO} \mathrm{SO}_{2}$ and approximately $8000 \mathrm{t} / \mathrm{d} \mathrm{HCl}$ with no ash emission. The observations of large $\mathrm{Cl}$ releases at Augustine support the $\mathrm{Cl}$ abundance conclusions of Johnston (1980) based on study of melt inclusions in the 1976 lavas. The results reinforce the need for more measurements during eruptions and for better understanding of scaling of volcanic emissions of various eruptive components.

\section{Introduction}

Augustine Volcano $\left(59.37^{\circ} \mathrm{N}, 153.42^{\circ} \mathrm{W}\right)$ is a symmetrical andesitic island volcano, located in lower Cook Inlet, 375 $\mathrm{km}$ SSW of Anchorage, Alaska (Figure 1). Augustine's summit $(1200 \mathrm{~m})$ is marked by a complex lava dome, while the flanks surrounding the volcano consist of a debris apron formed by pyroclastic flows. Recorded historic activity consists of six explosive Peléean eruptions that were of ten followed by lava extrusions. These

\footnotetext{
1Michigan Technological University, Houghton.

2 Los Alamos National Laboratory, New Mexico. ${ }^{3}$ Chemistry Department, University of Washington, Seattle. ${ }^{4}$ Brunswick Corporation, Costa Mesa, California.
}

Copyright 1988 by the American Geophysical Union.

Paper number 7B7080.

0148-0227/88/007B-7080\$05.00 occurred in 1812,1883,1935,1963-1964, 1976, and 1986 [Kienle and Swanson, 1985; Yount et al., 1987]. Because of the proximity of Augustine Volcano to the major north Pacific air routes, eruptive activity poses potential hazards to air traffic; previous eruptions have resulted in serious encounters [Kienle and Shaw, 1979; Rose, 1986].

Volcanological research at Augustine during and following the 1976 eruption focused on the transport and dispersal of the 1976 plume [Kienle and Shaw, 1979], the petrology of lavas [Johnston, 1978], the unusually chloride-rich nature of its volatiles [Johnston, 1980], aircraft sampling of eruption clouds [Hobbs et al,, 1977], and the seismicity of the volcano [D. J. Lalla, Ph. D. thesis, in preparation, 1980]. Seismic monitoring of Augustine detected weeks of precursory seismic activity before the 1986 eruption [Kienle, 1986].

Studies of gas emission rates at active volcanoes have emphasized the use of the correlation spectrometer (Cospec) for $\mathrm{SO}_{2}$ emission studies [Stoiber and Jepson, 1973; Casadevall et al., 1981]. The Cospec is very versatile for measurements during quiescent periods, and our understanding of rates and emission patterns during repose now includes direct measurements at more than 50 different fuming volcanoes. Notable problems in using the Cospec during eruptions are the opacity of cloud and the hazard of access by aircraft. Therefore direct data collected during eruptive periods (high emission rates) are still rare.

Estimates of the global volcanic degassing rates differ because of uncertainty in the estimates of degassing during large eruptions [Berresheim and Jaeschke, 1983; Stoiber et al., 1987]. Indirect estimates of eruptive degassing [Leavitt, 1982; Devine et al., 1984] may be criticized [Rose et al., 1981, 1983] because they are based on poorly-constrained erupted magma volumes and do not reflect contributions from intrusive magma. Krueger [1983, 1985] demonstrated the use of the total ozone mapping spectrometer (TOMS) as a synoptic satellite sensor of $\mathrm{SO}_{2}$ released during eruptions. The quantitative potential of such remotely-sensed data can be augmented by simultaneous ground-based measurements. Direct measurements of emission rates of other gas species $\left(\mathrm{CO}_{2}\right.$, $\mathrm{H}_{2} \mathrm{O}$ ) are rare [Harris et al., 1981], but the Cospec data, together with other sampling methods, have now been applied to estimate the emission rates of other gases, ash, aerosols, and volatile metal species [Casadevall et al., 1984; Chuan et al., 1986; Rose et al., 1986; Lepel et al., 1978]. The objectives of this study were to make direct measurements of the $\mathrm{SO}_{2}$ emission rates during explosive eruption of Augustine Volcano and to simultaneously collect other data that would allow evaluation of the emission rates of other gases and volcanic ash and aerosol particles of various sizes. A principal aim of the work is to determine how to scale from low-level activity which is easily observed and measured to large-scale explosive eruptions which are of ten unapproachable. We can thus estimate more accurately the relative and absolute amounts of material added to the atmosphere. We also hope that the direct flux measurements of this eruption can provide a calibration for weather-satellite detectors of ash clouds and sulfur dioxide. When calibrated, the synoptic satellite measurements will allow hazards to be quickly 


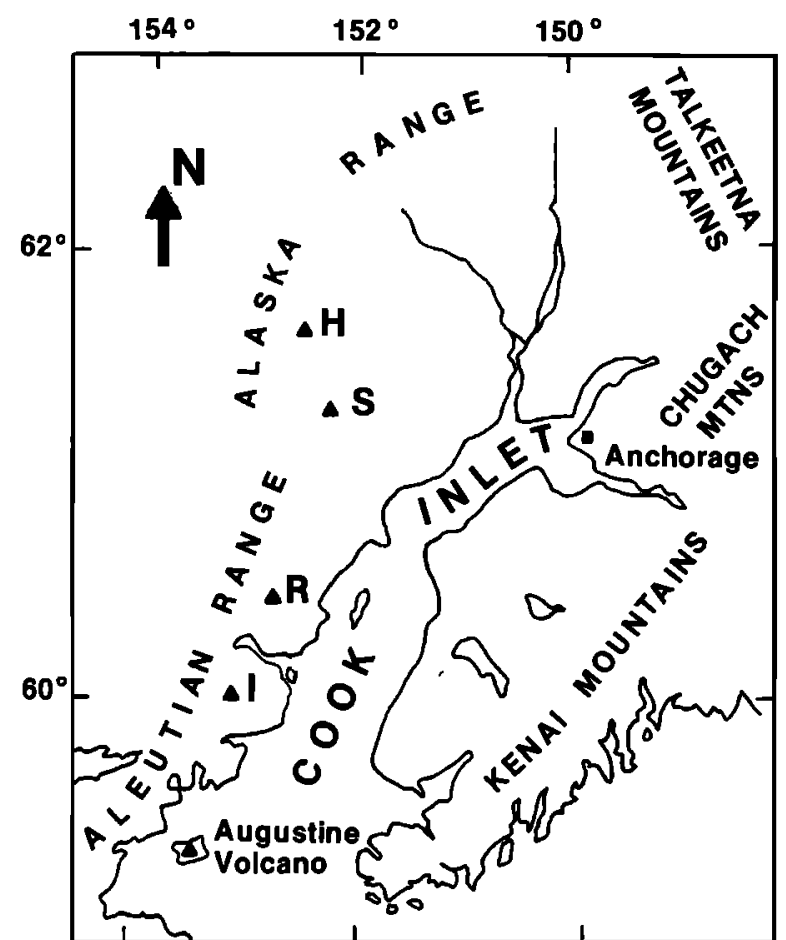

Fig. 1. Location map of Augustine Volcano and other volcanoes of the Cook Inlet area. I,Iliamna; R,Redoubt; S,Spurr; and H,Hayes (modified from Yount et al. [1987]).

characterized, tracked, and forecast on a worldwide basis. This paper focuses on the source characteristics, while a companion paper [G. Heiken et al., manuscript in preparation, 1988.) will address the dispersal and fallout patterns of the eruption clouds.

\section{Methods}

Measurements of $\mathrm{SO}_{2}$ fluxes were made with a correlation spectrometer (Barringer Cospec-V) by an aircraft survey method [Casadevall et al., 1981]. The instrument's telescope, directed upward, detects absorption of ultraviolet skylight as the plane traverses under the plume, perpendicular to its dispersal axis. Such measurements give a quantitative cross section of the $\mathrm{SO}_{2}$ burden, which is multiplied by the wind speed to give the emission rate. The aircraft contained a LORAN navigation device for wind speed determinations. Because the wind speed, our largest source of error, was well measured, we estimate that our individual flux measurements are accurate to about $\pm 15 \%$ of the rates reported. We monitored the automatic gain control of the instrument to verify that opacity did not reach critical levels.

Measurements of other components were made by direct plume sampling. Air was brought into the aircraft through two aluminum sampling probes which entered at a gentle angle through holes in the aircraft window. The aluminum tubes were lined with flexible plastic tubing of the proper size to fit snugly over the expansion cones which were connected to the top of the filter packs. This arrangement allowed two filter packs to sample simultaneously. The first filter pack contained a series of four base-treated (1 $\left.M^{7} \mathrm{LiOH}\right)$ Whatman filters to collect $\mathrm{SO}_{2}, \mathrm{HCl}$, and other acidic gases and was preceded by a fluorpore filter to collect particles. The second filter pack contained a series of four charcoal filters preceded by a fluorpore particle filter. Half of each sample was prepared for instrumental neutron activation analysis (INAA). The remaining half filters were archived; in the case of the base treated filters, one fourth of the filter was used to analyze for water soluble $\mathrm{SO}_{4}=$ and $\mathrm{SO}_{3}=$ by ion chromatography.

Particle measurements were made with a four-stage cascade impactor with quartz crystal microbalance impactor plates [Chuan, 1975], which separates airborne particles into four aerodynamic size groups. The mass of particles in each size group was determined and the particles were individually studied with scanning electron microscopy (SEM) and $X$ ray energy spectroscopy (XES).

\section{Results of Measurements on April 3, 1986}

For successful Cospec measurements during an explosive eruption, the plume must have a favorable geometry (ideally a regular lateral dispersion) and it must be sufficiently transparent so that absorption can be well measured. On April 3, 1986, the combination of clear atmospheric conditions, moderate activity and very high winds (45 knots or $23.1 \mathrm{~m} / \mathrm{s}$ ), precluded opacity and allowed absorption measurements. Traverses under the plume at low altitude $(155 \mathrm{~m})$ about $12 \mathrm{~km}$ downwind of the crater were possible because of the WNW direction of the winds and the lee wave geometry, which raised the plume above the sea surface (Figure $2 a$ ).

Contemporaneous Landsat (Figure 2b) and weather-satellite imagery is available for comparative study. Results of the Cospec survey are given in Table 1 . The mean $\mathrm{SO}_{2}$ emission rate, $24,000 \mathrm{t} / \mathrm{d}$, is one of the highest ever measured although it is probably small compared with explosive eruptions; other examples are listed in Table 2.

Filter samples collected by flying a longitudinal traverse along the edge of the eruption plume for $56 \mathrm{~min}$ allowed chemical characterization of the eruption cloud (Table 3 ). The gas collected on treated filters and particles collected on fluorpore filters were analyzed for 19 elements. The gas:particle proportions of $\mathrm{S}$ and $\mathrm{Cl}$ are about 10:1 and $4: 1$, respectively. The proportion of gaseous $\mathrm{S}: \mathrm{Cl}: \mathrm{Br}$ is about 290:250:1. Many of the elements (Al, Ca, Ti, Mn, $\mathrm{Sc}$, and $\mathrm{V}$ ) reflect the ash of the plume, being detected mainly in the particle filters and being present in the same proportions as the Augustine dacite [Yount et al., 1987]. Figure 3 plots enrichment factors calculated for each element based on analyses of dacitic ash samples from Augustine. Although it is possible that the bulk composition of the plume particles could differ from the ash by processes of atmospheric fractionation (e. g., selective fallout of denser components), this was not observed. The plots show that most of the analyzed elements are present in essentially the same proportions found in the ash samples. $\mathrm{Cl}, \mathrm{Br}$ and $\mathrm{S}$ (the latter is not plotted) are substantially enriched in the aircraft samples. Because these elements are also most enriched in the filters that trap gases, we interpret this to reflect volatile transport during eruption, by mechanisms similar to those described at volcanic fumaroles [Stoiber and Rose, 1974; Symonds et al., 1987b] and in plumes from fuming volcanoes [Rose et al., 1982, 1986; Casadevall et al., 1984; Chuan et al., 1986] and small eruption clouds [Rose et al., 1980]. A few of the cation species detected in the aircraft samples $(\mathrm{Zn}, \mathrm{Sb}, \mathrm{Cr})$ may reflect enrichments due to volatile transport, but such enrichments are very slight and contrast strikingly with the large enrichments of many cations detected in plumes from fuming volcanoes [Lepel et al., 1978; Phelan et al., 1982; Zoller et al., 1983]. The small enrichments we observed are probably due to the large ash flux which masks significant volatile enrichment in the erupted gas. 


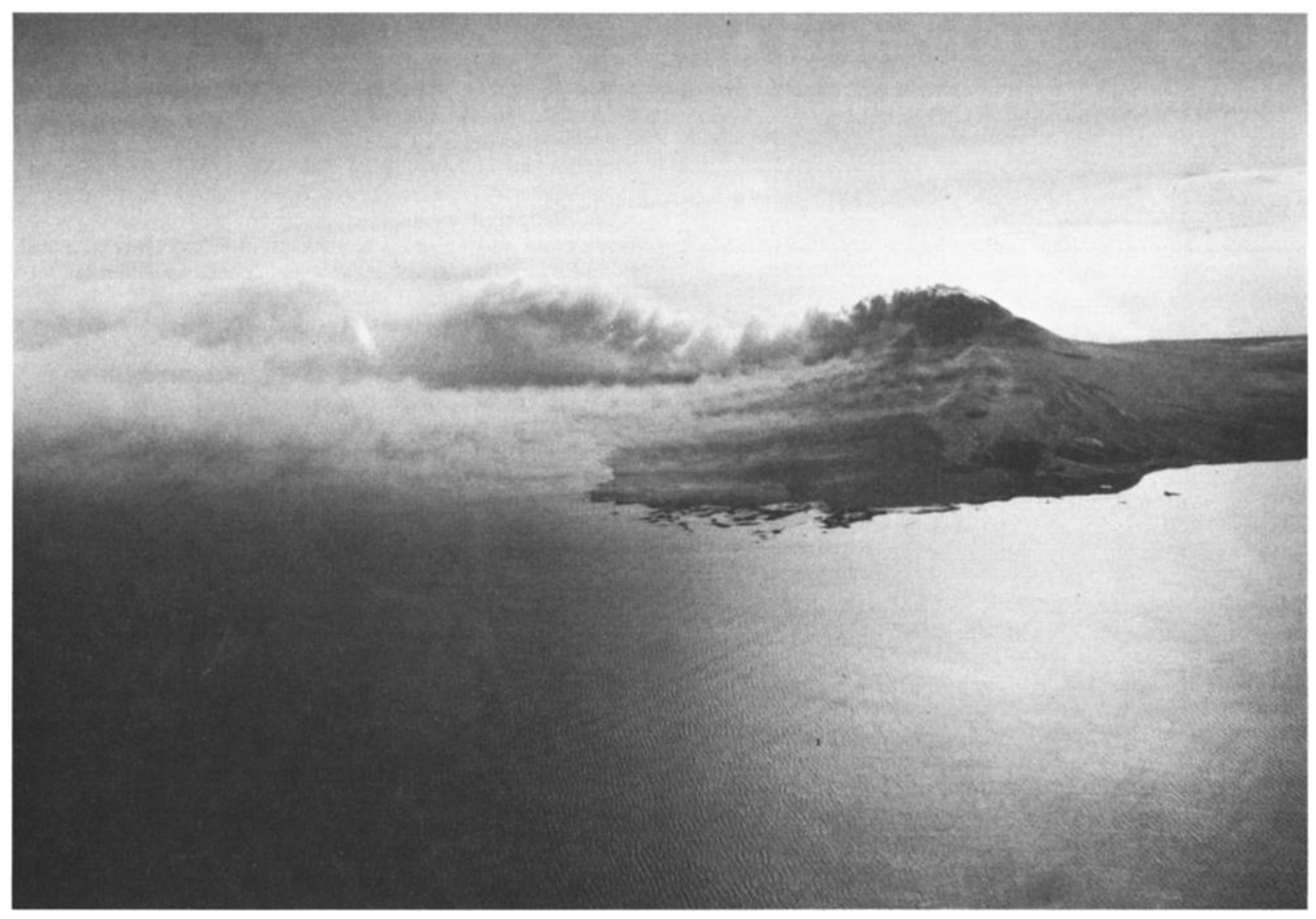

Fig. 2a

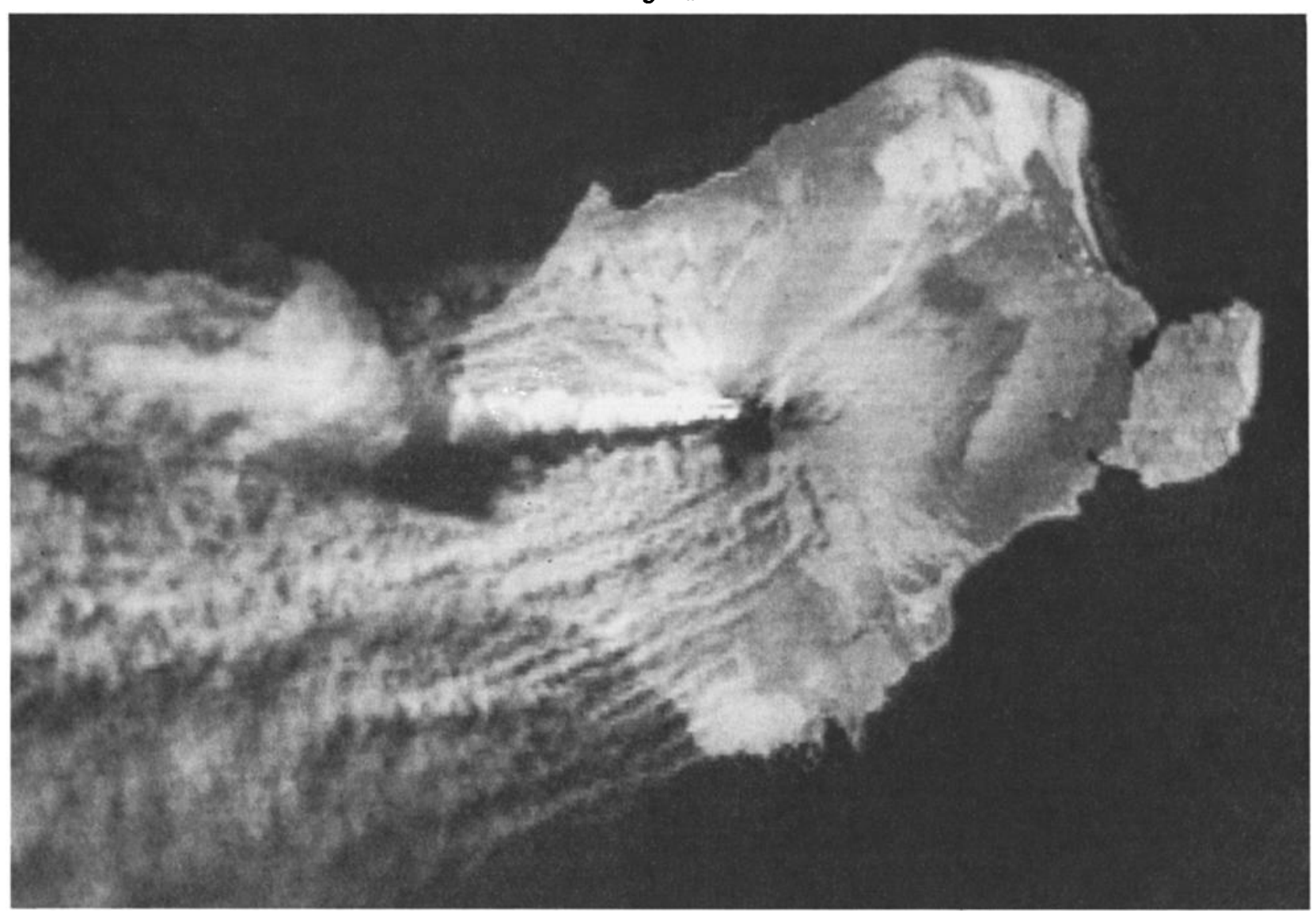

Fig. 2b

Fig. 2. Photographs of Augustine Volcano, 3 April 1986. (a) view from aircraft at 1100 am AST, showing the lee wave dispersion of the eruption plume. (b) Landsat image taken at 1319 AST. Only the SE corner of the image is shown. 
TABLE 1. $\mathrm{SO}_{2}$ Flux From Augustine Volcano Determined by Aircraft Survey With Corretion Spectrometer, April 3, 1986

\begin{tabular}{cccc}
\hline $\begin{array}{c}\text { Traverse } \\
\text { Number }\end{array}$ & $\begin{array}{c}\text { Plume Width, } \\
\text { km }\end{array}$ & Time, AST & $t / d$ \\
\hline 2 & 18.6 & 1141 & 19,700 \\
3 & 20.5 & 1153 & 28,400 \\
4 & 18.1 & 1205 & 20,400 \\
5 & 17.6 & 1213 & 24,500 \\
6 & 18.1 & 1224 & 26,100 \\
Mean & & \multicolumn{2}{c}{24,000 rounded } \\
\hline
\end{tabular}

Clear visibility, winds $250^{\circ}$ at 45 knots

(Loran) $(22.5 \mathrm{~m} / \mathrm{s})$, air speed 155 knots $(77.5 \mathrm{~m} / \mathrm{s})$. Highest flux of $\mathrm{SO}_{2}$ yet measured with Cospec, Kilauea East Rift Zone eruption measurements suggest 18,000 and $27,000 \mathrm{t} / \mathrm{d}$ during eruptions [Greenland et al., 1985]; previous Augustine activity in 1976 estimated with different method was $86,000 \mathrm{t} / \mathrm{d}$ [Stith et al., 1978].

Observations on previous two days (April 1 and 2, 1986) suggest that the rate of $\mathrm{SO}_{2}$ emission during the main part of the activity (March 27 to April 2) was higher than the April 3 rate. On April 2, the altitude interval of 5000 to $15,000 \mathrm{ft}$ between Anchorage and Mount Augustine contained about 200 $\mathrm{ppm} m$ of $\mathrm{SO}_{2}$. Although the mass is not well constrained, we estimate it to represent about 70,000 $t$ of $\mathrm{SO}_{2}$.

Because we measured the relative amounts of elements and specifically measured sulfur dioxide gas, we can calculate estimates of the flux rate of 18 elements by multiplying a ratio (the abundance of each element in the plume divided by the abundance of gaseous S) by the flux rate of $\mathrm{S}$ as $\mathrm{SO}_{2}$ observed by the Cospec. The proportion of $\mathrm{S}$ to $\mathrm{Cl}$ in the plume is about 1.2 and the calculated eruptive flux of $\mathrm{HCl}$ is therefore $10,000 \mathrm{t} / \mathrm{d}$. This result supports the conclusions of Johnston [1980] who showed that Augustine releases proportionally large amounts of $\mathrm{Cl}$ when compared with other volcanoes (see Table 4 for data from other volcanoes). Volcanoes in a convergent plate boundary setting erupt magmas with higher water and $\mathrm{Cl}$ contents [Anderson, 1974].

The mass proportions of silicate materials in the plume can be calculated from the concentrations of Sc, Al, Ca, and $\mathrm{Ti}$ in the filter samples (Table 3 ) because these elements are present in the same proportions as they are in Augustine dacite ash (Table 5). From this data we estimate an ash: $\mathrm{SO}_{2}$ proportion of about 70:1 and an ash emission rate on April 3 of about $1.5 \times 10^{6} \mathrm{t} / \mathrm{d}$.

The size distribution of eruption cloud particles (Figure 4) was directly determined with the particle cascade sampler, and the morphology and composition of individual particles were studied in the laboratory using SEM and XES (Figure 5 and Table 6). Results confirm the presence of dacitic ash as a dominant component. Many of the largest particles are shards with a high $\mathrm{Si}$ content. There are also numerous Al-and Si-rich, tabular and elongate particles which are probably feldspar. $\mathbf{S}$ and $\mathrm{Cl}$ are present in barely detectable concentrations, usually as surface coatings of silicate grains. Data from Yount et al [1987] show that the ashes which fell from March 28 to April 3, 1986 contain an average of $0.08 \% \mathrm{~S}$ and $0.11 \%$ Cl. The proportions of soluble $\mathrm{S}$ and $\mathrm{Cl}$ on Augustine ash is also about $1: 1$. Some halite is observable, either sea salt or volcanic sublimate [see also Rose et al., 1986]. A notable abundance of Fe-rich particles (probably Fe oxide) is mainly associated with aggregates of particles. The SEM observations are consistent with the filter results, showing that the particulate material in the cloud is predominately dacite ash with Fe-rich particles, halite, and some particulate acid. The low amounts of $\mathrm{S}$ and $\mathrm{Cl}$ observed during the XES study are consistent with the high gas:aerosol proportions for $\mathrm{S}$ and $\mathrm{Cl}$ indicated by the

TABLE 2. Estimates and Direct Measurements of $\mathrm{SO}_{2}$ Emission Rates During Volcanic Activity

\begin{tabular}{lcrc}
\hline Volcano & Date & $\begin{array}{c}\mathrm{SO}_{2} \text { Emission Rate, } \\
\mathrm{t} / \mathrm{d}\end{array}$ & Reference \\
\hline Kilauea & $1983-1984$ & $1-3 \times 10^{4}$ & 1 \\
Augustine & Apri1 3,1986 & $2.4 \times 10^{4}$ & this paper \\
Augustine & Feb. 13,1976 & $8.6 \times 10^{4}$ & 2 \\
Fuego & 1974 & $2 \times 10^{6}$ & 3 \\
Mount St. Helens & May 1980 & $6 \times 10^{6}$ & 4 \\
\hline
\end{tabular}

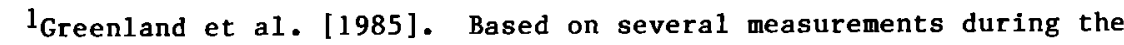
episodes of the East Rift Zone sequence of 1983-1986. Some of these measurements were probably underestimating the flux because the Cospec signal was saturated.

${ }_{2}$ Hobbs et al. [1977]. Based on measurements of $\mathrm{SO}_{2}$ concentrations inside an eruption cloud, measurements of the duration of the explosion, and assumptions about its expansion with time.

${ }^{3}$ Rose et al. [1981]. An indirect estimate, based on diverse data collected from samples of erupted rocks (melt inclusions, adsorbed volatiles), study of ashes, aerosols, and gases collected within small eruption clouds from the same volcano during low-level activity and various untested assumptions.

4Millan et a1. [1985]. A very long range Cospec determination made in Toronto as the Mount St. Helens plume traversed North America on June $20-22,1980$, and based on assumptions about the plume geometry. 
TABLE 3. Concentrations of Elements (in micrograms $\mathrm{m}^{-3}$ ) on Filters Collected on April 3, 1986, During 56 Minutes of Flying Inside the Augustine Eruption Plume

\begin{tabular}{|c|c|c|c|c|}
\hline Element & $\frac{\text { Base-Treatec }}{\text { Aerosol }}$ & $\frac{\text { d Filters }}{\text { Gas }}$ & $\frac{\text { Charcoal }}{\text { Aerosol }}$ & $\frac{\text { Filters }}{1 \quad \text { Gas }}$ \\
\hline $\mathrm{Na}$ & 922 & & 724 & \\
\hline $\mathrm{K}$ & 325 & & 256 & \\
\hline $\mathrm{C} 1$ & 29.8 & 138 & 30.0 & 120 \\
\hline Mn & 14.3 & 0.732 & 10.3 & \\
\hline $\mathrm{Ba}$ & 23.0 & & 15.3 & 13.2 \\
\hline $\mathrm{Mg}$ & 206 & & 210 & \\
\hline Al & 1760 & 1.92 & 1240 & \\
\hline $\mathrm{Ca}$ & 764 & & 588 & 724 \\
\hline $\mathrm{Ti}$ & 72.4 & & 44.0 & \\
\hline $\mathrm{V}$ & 2.54 & 0.00432 & 1.67 & \\
\hline $\mathrm{Ga}$ & 0.476 & & 0.386 & \\
\hline As & 0.0656 & & 0.0732 & \\
\hline $\mathrm{Br}$ & & 0.552 & 0.058 & 5.23 \\
\hline $\mathrm{Sb}$ & 0.00964 & 0.0325 & 0.0160 & 0.030 \\
\hline La & 0.440 & 0.0778 & 0.348 & \\
\hline $\mathrm{Sm}$ & 0.106 & 0.0008 & 0.0876 & \\
\hline $\mathrm{Yb}$ & 0.0808 & 0.0490 & 0.0544 & 0.0440 \\
\hline Lu & 0.00996 & & 0.00992 & \\
\hline W & & & 0.48 & 0.0686 \\
\hline Sc & 0.334 & 0.001 & 0.254 & 0.002 \\
\hline $\mathrm{Cr}$ & 1.05 & 0.476 & 0.664 & 0.492 \\
\hline $\mathrm{Fe}$ & 984 & 0.940 & 736 & 11.2 \\
\hline Co & 0.330 & 0.099 & 0.248 & \\
\hline $2 \mathrm{n}$ & 1.18 & & 0.998 & 1.87 \\
\hline $\mathrm{Rb}$ & 0.624 & & 0.464 & \\
\hline Cs & 0.0186 & & & \\
\hline $\mathrm{Ce}$ & 0.976 & & 0.768 & 0.0822 \\
\hline Eu & 0.0292 & & 0.0306 & \\
\hline Tb & 0.0256 & & 0.0212 & \\
\hline $\mathrm{Hf}$ & 0.166 & & 0.144 & 0.021 \\
\hline $\mathrm{Ta}$ & 0.0128 & & & \\
\hline $\mathrm{Pa}$ & 0.118 & & 0.0968 & 0.0034 \\
\hline $\mathrm{Ag}$ & & 0.0114 & & \\
\hline $\mathrm{Sr}$ & & & & 20.3 \\
\hline $\mathrm{s}$ & 17.1 & 159 & 16.6 & * \\
\hline
\end{tabular}

* Only particulate sulfur could be determined.

filter samples. Thus the high proportion of volcanic ash dilutes the aerosol $\mathrm{S}$ and $\mathrm{Cl}$ to low concentrations.

\section{Meteorology and Plume Dispersion Modeling}

Having measured the emission rate and using appropriate weather data, it is possible to model dispersion. We wanted to accomplish this to allow for ground-truth calibrations with satellites. Although only raw imagery from the weather satellites is presently available, we feel that detailed examination could develop a quantitative satellite monitoring ability for both $\mathrm{SO}_{2}$ and volcanic ash. It is especially important to calibrate the concentrations of ash and $\mathrm{SO}_{2}$ with the satellite data, and dispersion modeling provides a way to convert ground-based measurements to a larger-scale plume/concentration map.

The eruption of April 3, 1986, occurred under a northwesterly airflow on the backside of a dissipating low-pressure system in the Gulf of Alaska. The pressure gradient was reasonably strong, giving rise to a vigorous west-northwesterly wind of $7-10 \mathrm{~m} / \mathrm{s}$ in the lowest kilometer of the atmosphere and increasing to $20 \mathrm{~m} / \mathrm{s}$ at the 500 mbar $(6 \mathrm{~km})$ level.

The 1000 mbar (surface) pressure map and the $500 \mathrm{mb}$ map at 0140 Alaska Standard Time (AST), April 3, are shown in Figure 6 . The sequence of positions of the low-pressure center at 12 hour intervals is shown in the 1000-mbar map. The low traveled east-northeastward at an average speed of $8 \mathrm{~m} / \mathrm{s}$ over the previous 72 hours. During the course of the period, winds in Cook Inlet evolved from southerly in advance of the storm through easterly, northerly, and becoming northwesterly at the 1400 AST map time.

The plume transport is governed by the winds in the volume of atmosphere occupied by the plume. In order to estimate this factor, we need to know the plume altitude, since the winds vary quite dramatically with height. The April 3 plume was sheared off at approximately the top of the volcano itself, $1227 \mathrm{~m}$ (Figure 2). Should it be considered an elevated plume at $1-1.5 \mathrm{~km}$ above the sea surface?

Figure 2 shows a distinct train of vertical oscillations (waves) in the plume as it travels downwind. In order to understand the plume transport we explored the conditions under which such waves are expected to develop.

Linear theories describing the important properties of mountain waves were developed in the 1940's [Lyra, 1943; Queney, 1948; Scorer, 1949]. For real, finite-sized obstacles in the boundary layer of frictional fluids, nonlinear analyses as described by Long [1955] or laboratory simulations have also been applied. For our purposes it is enough to recognize that air displaced vertically over an obstacle in a stable atmosphere will encounter a buoyant restoring force and will oscillate at the Brunt-Vaisala frequency:

$$
N=\left[\frac{\delta}{\delta} \frac{\delta}{\delta z}\right]^{1 / 2}
$$

where $\theta$ is the potential temperature, $g$ is the acceleration of gravity, and $z$ is the vertical dimension. If

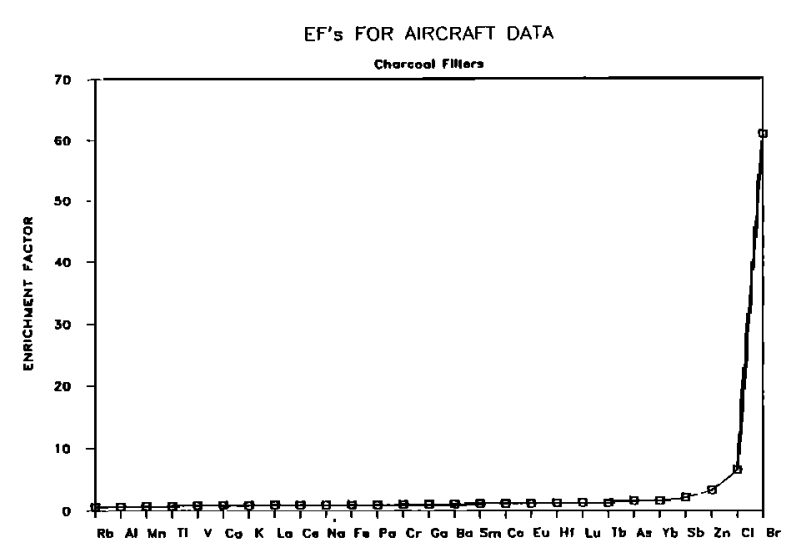

Fig. 3. Calculated enrichment factors (EF) or the charcoal sample pack collected on April 3, 1986. Enrichment factors are calculated for each element based on the ratio of that elements concentration to the Scandium concentration divided by the same ratio for Augustine dacite, as determined from the analyses of airfall ashes (Table 5). Except for $\mathrm{Br}, \mathrm{Cl}$, and a few very slight enrichments in other elements, the flat shape of this plot indicates that the eruption plume of April 3 was dominated by dacite ash, and the large enrichments of certain metals detected in volcanic plumes are absent (see text for discussion). 
TABLE 4. Comparison of Some Measured and Estimated Rates of $\mathrm{SO}_{2}$ and $\mathrm{HCl}$

Emission Rates at Various Volcanoes at Different Eruptive States

\begin{tabular}{|c|c|c|c|c|}
\hline Volcano & Date & $\mathrm{SO}_{2}, \mathrm{t} / \mathrm{d}$ & $\mathrm{HCl}, \mathrm{t} / \mathrm{d}$ & Reference \\
\hline
\end{tabular}

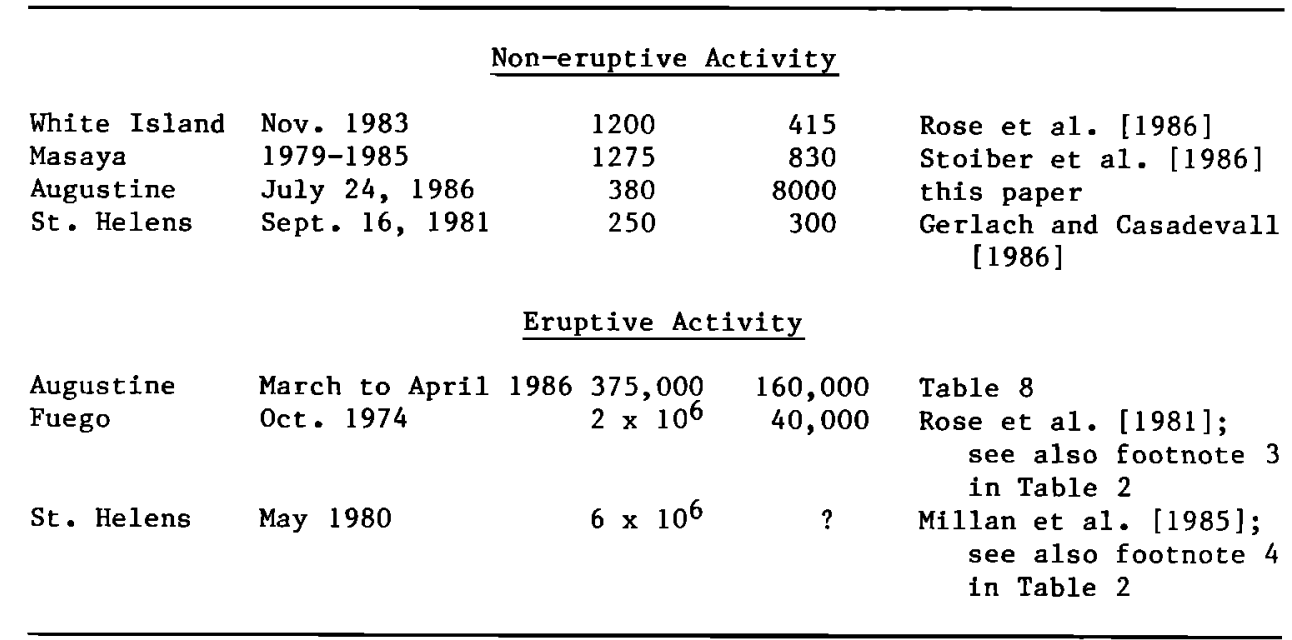

the parcel is transported downwind by a net velocity $U$ while it is oscillating, it will describe a wave pattern with wavelength $t=2 \pi U / N$. An important dimensionless parameter that describes the ratio of inertial force to buoyant force, and therefore properties of vertically displaced flow in stable atmosphere, is the Froude number, $F=U / N h$. $U$ is the upstream wind speed and $h$ the height of an obstacle. Hunt et al., [1978] present laboratory simulations of flows at a range of Froude numbers. At $F<0.5$ the flow separates from the lee side of a circular hill. At $F>1$ the lee wavelength is long compared with the obstacle dimension, and separation occurs. However, between those values the flow hugs the hill contour, as shown in Figure 7. Notice at $F=0.8$ a second wave node is present at about one hill diameter downstream, similar to the pattern shown in Figure 2.

Meteorological data can be used to confirm similar Froude numbers. Analyzed large-scale meteorological data from the $2.5^{\circ}$ resolution northern hemisphere grid were available, and we selected the grid point nearest in space and time to the Augustine eruption: $60^{\circ} \mathrm{N}, 152.5^{\circ} \mathrm{W}$ and 1500 AST on April 3. The temperature profile in the lowest $1500 \mathrm{~m}$ gives $\mathrm{N}=0.012 \mathrm{~s}^{-1}, \mathrm{U}=8.5 \mathrm{~m} \mathrm{~s}^{-1}$. With $h=1227 \mathrm{~m}$, these values yield $\mathrm{F}=0.6$, equivalent to those shown between Figures $7 \mathrm{a}$ and $7 \mathrm{~b}$. The large-scale meteorological data are smoothed and not necessarily representative of the local conditions at the time of the photograph in Figure 2. The large-scale gridded wind speeds are lighter than were actually occurring at Augustine during the eruption. Wind speeds downwind of Augustine were measured by the LORAN aboard the aircraft at $22 \mathrm{~m} \mathrm{~s}^{-1}$. How does this speed influence our estimate of the Froude number and the observed wavelength? The observed wavelength appears to be $8 \mathrm{~km}$ $\pm 2 \mathrm{~km}$ from the aerial photographs. For comparison, $\tau=2 \pi \mathrm{U} / \mathrm{N}=2 \pi(22) /(0.012)=11 \mathrm{~km}$, quite

good agreement. The corresponding Froude number is 1.5 . Thus we feel that our data and observations constrain a consistent model.

We note that the wave motion (Figure 2) undergoes some decay due to a turbulent mixing beyond the second node. We estimate the effective source to be uniformly mixed between sea level and $1.2 \mathrm{~km}$ altitude. In that layer, the mean wind direction from the gridded analysis is from $297^{\circ}$ with a directional shear of $8^{\circ}$ between sea level ans $1500 \mathrm{~m}$. In addition to the lateral spread due to mixing within the shear from sea level to the top of the plume, we must consider horizontal growth due to horizontal turbulence processes. The empirical relationship derived by Heffter [1965] is remarkably simple and difficult to improve upon for mesoscale horizontal spread. We will adopt:

$$
\sigma_{y}=0.5 \mathrm{t}(\mathrm{s})
$$

where $\sigma_{y}$ is the lateral standard deviation of a quasi-gaussian concentration distribution. This adds another $5^{\circ}$ to the lateral spread. With the lateral and vertical dimensions of the plume estimated out to 6 hours of travel, we have enough information to estimate air concentrations, provided that we have an estimate of source strength. Applying the gaussian plume dispersion formula for a plume mixed uniformly in the vertical from 0 to $L=1200 \mathrm{~m}$ :

$$
C / Q=\left[\sqrt{ } \frac{1}{(2 \pi) \sigma_{y} L} U\right] \exp \left(-0.5\left[\frac{Y}{\sigma_{y}}\right]^{2}\right\}
$$

Substituting for $\sigma_{y}, L$, and $U$ into (1), we arrive at a simple expression for the axial concentration at a downwind distance, $x$ :

$$
C\left(\mathrm{~kg} \mathrm{~m}^{-3}\right) / \mathrm{Q}\left(\mathrm{kg} \mathrm{s}^{-1}\right)=6.6 \times 10^{-4} \mathrm{x}^{-1}\left(\mathrm{~m}^{-1}\right)
$$

Since we introduced a dimensional empirical relationship for $\sigma_{\mathrm{y}}$, we must be very careful to use mks units in applying (3). Using the estimated $\mathrm{SO}_{2}$ emission of $24,000 \mathrm{t} / \mathrm{d}\left(280 \mathrm{~kg} \mathrm{~s}^{-1}\right)$ : $\begin{aligned} \mathrm{C}\left(\mathrm{SO}_{2}\right) & =\underset{ }{\left[(280)\left(6.6 \times 10^{-4}\right)\right] /\left(9 \times 10^{4}\right)=2 \times 10^{-6} \mathrm{~kg} \mathrm{~m}^{-3}} \\ & \approx 1 \mathrm{ppm}(\text { by volume })\end{aligned}$ 
TABLE 5. Bulk Chemistry of Ash Samples Using INAA

\begin{tabular}{|c|c|c|c|}
\hline Element & Ash A & Ash $K$ & Ash 1A \\
\hline $\mathrm{Na}$ & 30,600 & 30,500 & 31,300 \\
\hline $\mathrm{Cl}$ & 1,087 & 919 & 1,090 \\
\hline $\mathrm{K}$ & 12,200 & 9,560 & 12,700 \\
\hline $\mathrm{Mn}$ & 426 & 580 & 630 \\
\hline $\mathrm{Ba}$ & 864 & 521 & 626 \\
\hline $\mathrm{Mg}$ & 12,500 & 28,300 & -- \\
\hline Al & 77,700 & 78,600 & 79,200 \\
\hline $\mathrm{Ca}$ & 37,400 & 40,000 & 29,800 \\
\hline $\mathrm{Ti}$ & 5,720 & 2,730 & 2,420 \\
\hline $\mathrm{V}$ & 91.8 & 133 & 85.7 \\
\hline $\mathrm{Ga}$ & 10.8 & 16.3 & 16.8 \\
\hline As & 3.04 & 1.68 & 3.00 \\
\hline $\mathrm{Br}$ & 5.17 & 3.36 & 4.18 \\
\hline Mo & 4.49 & -- & -- \\
\hline $\mathrm{Sb}$ & 1.12 & 5.06 & 1.18 \\
\hline La & 15.0 & 13.1 & 16.6 \\
\hline Nd & 17.9 & 13.5 & 14.3 \\
\hline $\mathrm{Sm}$ & 3.80 & 3.61 & 3.41 \\
\hline $\mathrm{Yb}$ & 2.79 & 2.64 & 2.83 \\
\hline $\mathrm{Lu}$ & 0.376 & 0.362 & 0.360 \\
\hline W & 1.23 & -- & -- \\
\hline $\mathrm{Au}$ & $9.50 \mathrm{~F}$ & 5.00 & $7.15 \mathrm{PP}$ \\
\hline $\mathrm{Np}$ & 1.88 & 1.45 & 2.08 \\
\hline $\mathrm{Sc}$ & 11.3 & 18.9 & 12.2 \\
\hline $\mathrm{Cr}$ & 23.0 & 51.1 & 29.9 \\
\hline $\mathrm{Fe}$ & 32,400 & 50,100 & 34,200 \\
\hline Co & 9.87 & 16.7 & 9.64 \\
\hline $\mathrm{Zn}$ & 111 & 55.6 & 41.6 \\
\hline Sr & 300 & 350 & 258 \\
\hline $\mathrm{Rb}$ & 31.4 & 25.2 & 33.3 \\
\hline $\mathrm{Ag}$ & 0.877 & -- & -- \\
\hline Sn & -- & 216 & -- \\
\hline Cs & 0.692 & 0.603 & 1.01 \\
\hline $\mathrm{Ce}$ & 31.7 & 18.8 & 36.3 \\
\hline Eu & 0.985 & 1.04 & 1.17 \\
\hline $\mathrm{Tb}$ & 0.715 & 0.675 & 0.763 \\
\hline $\mathrm{Hf}$ & 5.15 & 4.18 & 5.34 \\
\hline $\mathrm{Ta}$ & 0.436 & 0.346 & 0.483 \\
\hline $\mathrm{Hg}$ & -- & 0.228 & -- \\
\hline $\mathrm{Pa}$ & 3.66 & 3.07 & 4.43 \\
\hline
\end{tabular}

Concentrations are in ppm, unless otherwise noted. Locations of ash samples are ash A; a cumulative sample (March 27 to April 2) collected near Anchorage; ash $\mathrm{K}$; collected on March 28 near Kenai; and ash 1A; a cumulative sample (March 27 to April 1) collected in the $\mathrm{NE}$ area of the Kenai Peninsula.

in the vicinity of the Barren Islands, $90 \mathrm{~km}$ downwind. Figure 8 shows the concentration isopleth for $\mathrm{C}\left(\mathrm{SO}_{2}\right)=1$ $x 10^{-6} \mathrm{~kg} \mathrm{~m}^{-3}$. Our flux determination can also be used to estimate the maximum concentrations of silicate ash within the contours in Figure 8 at about 125 and $63 x$ $10^{-6} \mathrm{~kg} / \mathrm{m}^{3}$. We expect that the application of this dispersion model can be used for calibration of satellites which detect volcanic plumes [Krueger, 1983; Matson, 1984] and detailed study of the relevant images has already begun.

\section{Results of July 1986}

In July 1986, more than two months after the explosive phases of activity, Symonds et al [1987a] sampled gases and condensates at high-temperature vents on the summit of Augustine and again made an airborne Cospec rate measurement. The conditions at that time were typical of those that prevail following major eruptions when the vent is freely fuming and emitting gases, and there was some extrusion of lava, but little or no eruption of ash. The Cospec results are in Table 7 . The $\mathrm{SO}_{2}$ emission rate was $380 \mathrm{t} / \mathrm{d}$, about $1.6 \%$ of the April value. Visual observations suggest that the ash content of the plume was low. The $\mathrm{HCl}$ flux of the plume in July can be estimated at $8000 \mathrm{t} / \mathrm{d}$, based on gas sampling and the Cospec data. Thus the S/Cl ratio of the July plume $(0.03)$ was lower than on April 3 (1.15). The July gas condensates also contained conspicuous enrichments of metals $(\mathrm{Zn}, \mathrm{Cu}, \mathrm{B}$, $\mathrm{Mo}, \mathrm{Fe}, \mathrm{Pb}, \mathrm{Na}, \mathrm{Al}, \mathrm{Ca}, \mathrm{As}, \mathrm{Zr}$ and $\mathrm{V}$ ), which could not be detected, probably because they were masked by the large ash flux during the April eruption.

\section{Bulk Chemistry of Ash}

We analyzed bulk samples of ash that fell at locations from 60 to $200 \mathrm{~km}$ from the volcano within the period of March 28 until about April 3. Because of their wide dispersal, these samples represent materials erupted during the highest columns and probably also the highest eruption rates. Neutron-activation analyses of these samples are listed in Table 5, and we also compared XRF determinations of Yount et al [1987] on similar materials. All are compositionally similar and also closely resemble the 1976 pumices.

\section{Discussion}

We are interested in whether our data are representative of explosive eruptions. Because the most detailed direct measurements to date have been made either on non-eruptive plumes [Rose et al., 1986], on very small small eruptions (much smaller than the 3 April activity at Augustine) [Rose et al., 1980] or at the extreme periphery of a large cloud [Hobbs et al., 1981], it is unclear whether the samples taken reflect conditions prevailing during the most intense eruptions when most material is released and when sampling is most difficult

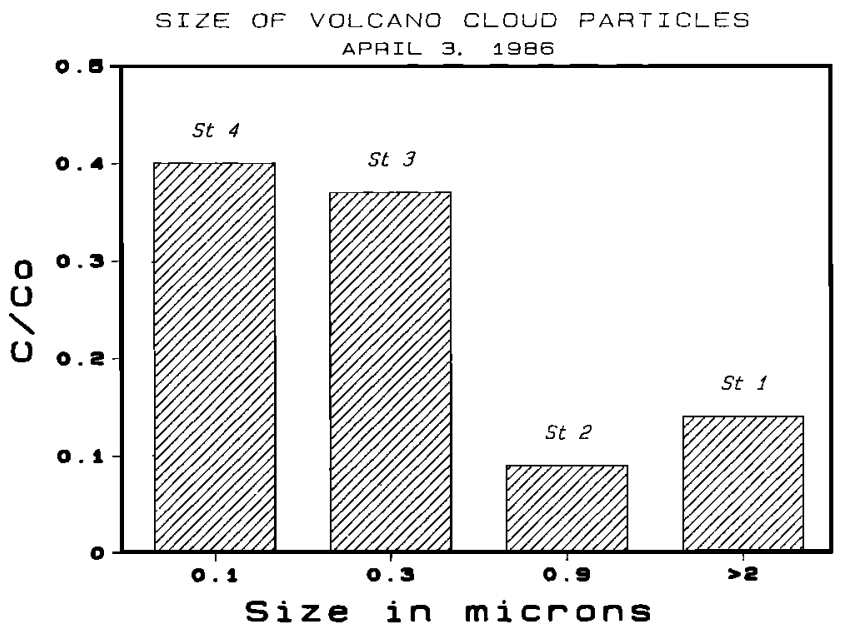

Fig. 4. The size distribution of particles that accumulated on the four stages of the Quartz Crystal microcascade sampler used on April 3, 1986. The size listed along the bottom of the figure is the $50 \%$ cutoff of isodynamically separated sizes [Chuan, 1975], assuming a density of 2 $\mathrm{g} / \mathrm{cm}^{3}$. The proportion of the total mass $\mathrm{C} / \mathrm{C}^{\circ}$ is plotted on the $y$ axis. 


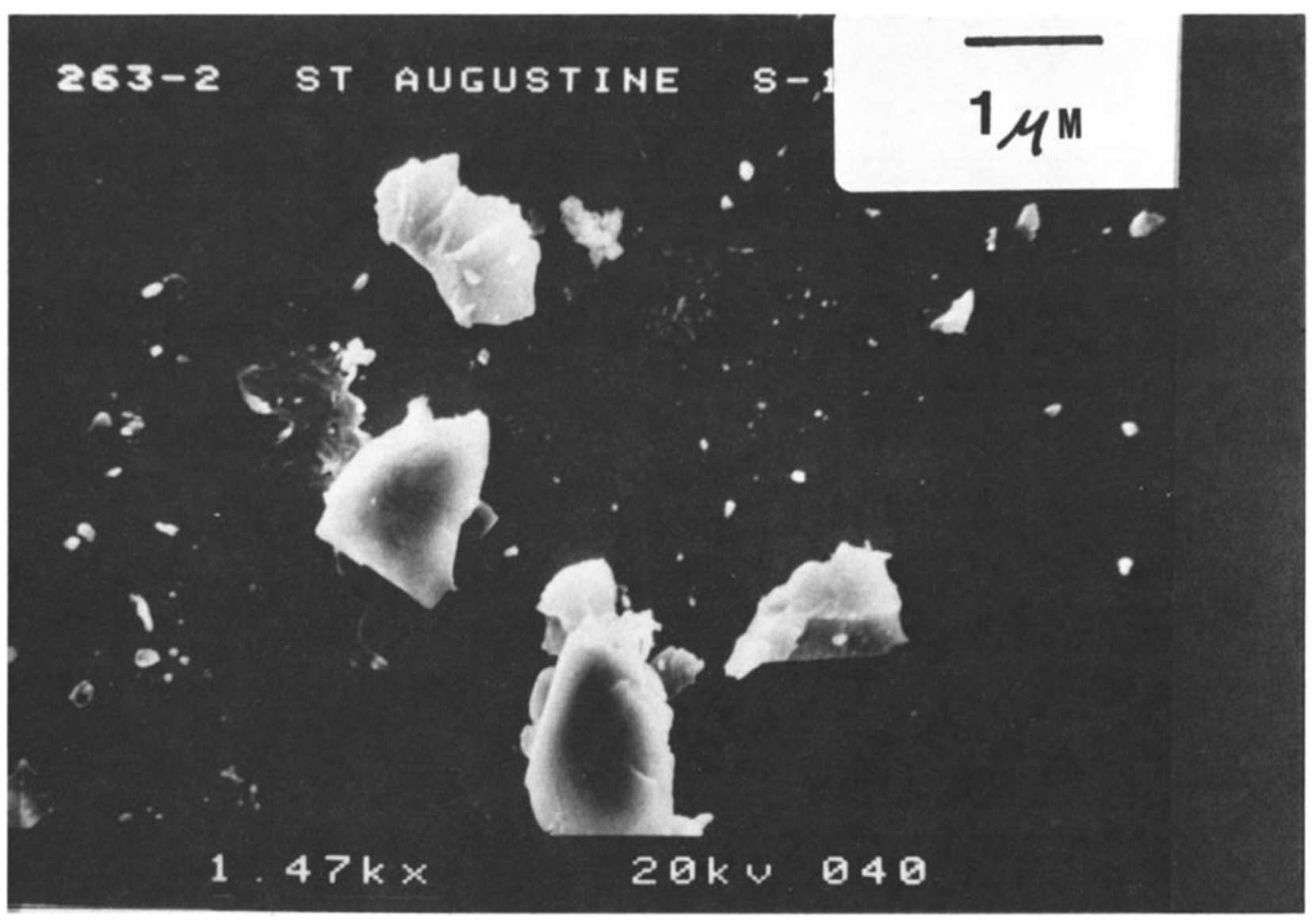

Fig. 5a

263-5 AUGUSTINE $S-1$

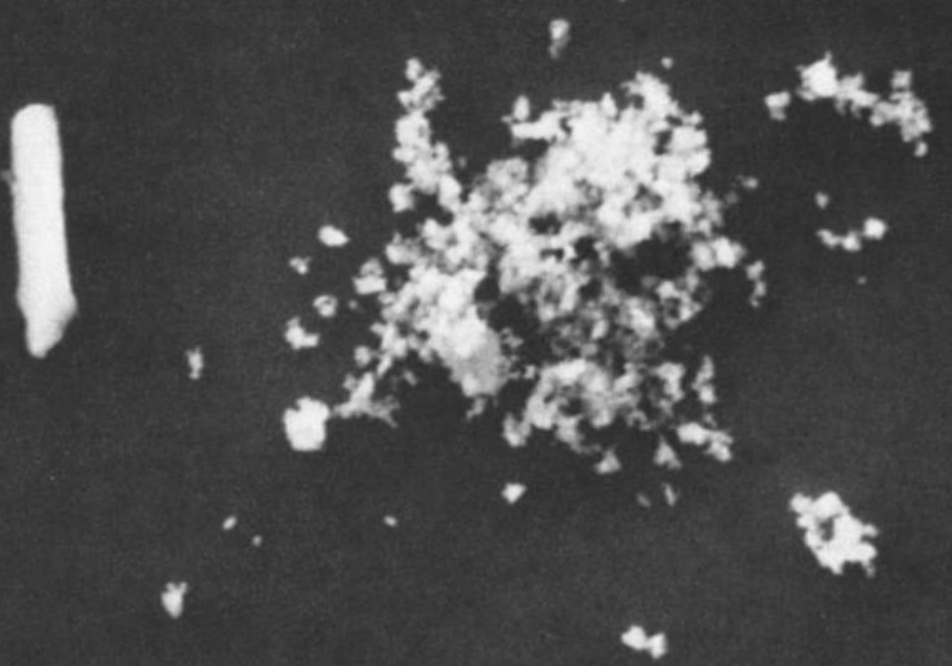

1. $6 k x$

$20 k \cup 015$

Fig. $5 b$

Fig. 5. Scanning electron microscope images of ash particles collected on the QCM at Augustine, April 3, 1986. (a) Some larger fragments of silicate material. (b,c, and d) Interpreted as aggregates which broke upon impact. See Table 6 for compositional information. S-1,stage 1; S-2,stage 2. 


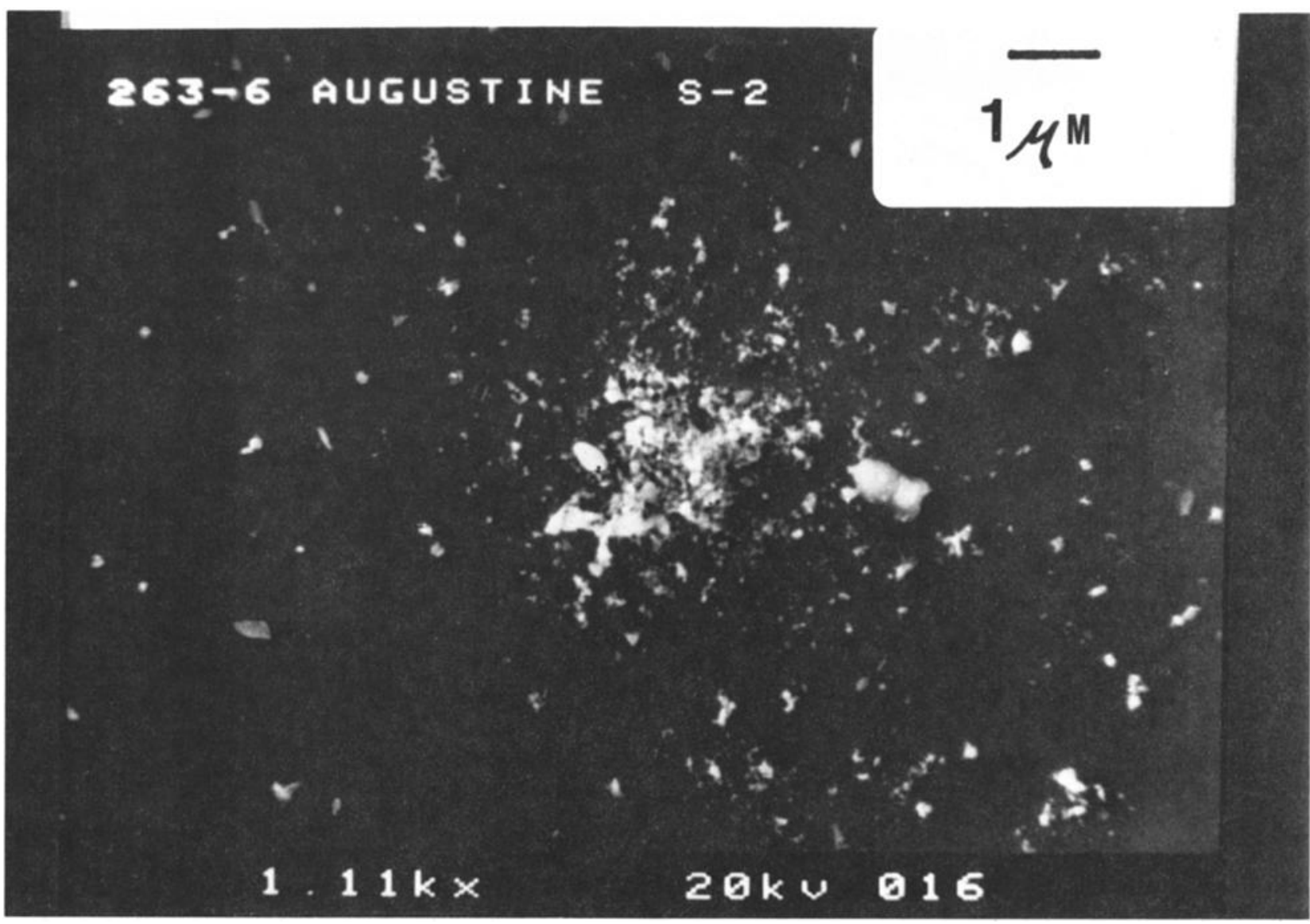

Fig. 5c

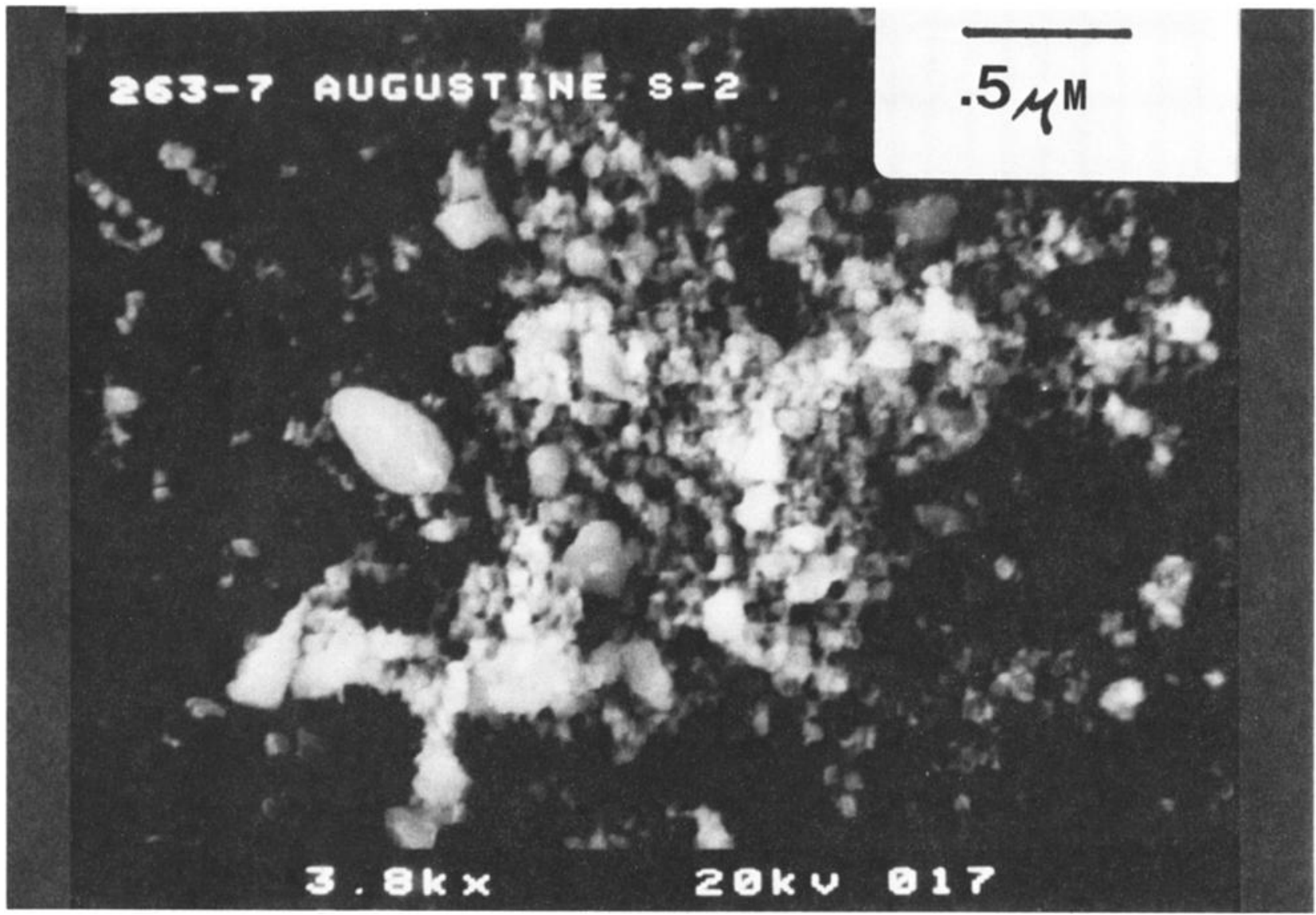

Fig. 5d 
TABLE 6. Summary of SEM Observations of Eruption Cloud Particles Sampled in the Augustine Plume of April 3, 1986 With Quartz Crystal Microcascade

\begin{tabular}{|c|c|c|c|}
\hline Stage & $\begin{array}{l}\text { Nominal } 50 \% \\
\text { Cutoff s, } \mathrm{m}\end{array}$ & $\begin{array}{c}\text { Observed Sizes, } \\
\text { m }\end{array}$ & Comment \\
\hline 1 & $>2$ & $\begin{array}{c}15 \times 25 \\
2 \times 2\end{array}$ & $\begin{array}{l}\text { Silicates (glass } \\
\text { or lithics), }\end{array}$ \\
\hline 2 & $0.4-2$ & $\begin{array}{l}\text { most } 1 \text { y } 1-2, \\
\text { aggregates } \\
\text { to }>5\end{array}$ & $\begin{array}{l}\text { with S and c1 } \\
\text { Silicates (glass } \\
\text { xtals) with } \\
\text { high } \mathrm{Cl} \text { and } \mathrm{s}, \\
\mathrm{NaCl} \text {, agg. rich } \\
\text { in Fe }\end{array}$ \\
\hline 3 & $0.2-0.4$ & $0.3-2$ & $\begin{array}{l}\text { Silicates (shards, } \\
\text { plag, amph) }\end{array}$ \\
\hline 4 & $0.05-0.2$ & $0.1-2$ & $\begin{array}{l}\text { Silicates with } \mathrm{Cl} \text {, } \\
\text { S }\end{array}$ \\
\hline
\end{tabular}

Particles were collected with the QCM during the same period as filter sampling, following the COSPEC traverses.

Unlike most plume samples during inactive fuming, all stages in this sampling are dominated by silicates. The particles are very fine grained and poorly sorted. Acid droplets are not obvious, probably flooded and scavenged by the silicates. High by the silicates. High $S$ and $C l$ in the samples account for several \% by wt of the particles. Some of the $\mathrm{Cl}$ is probably $\mathrm{NaCl}$, perhaps sea salt. The ash is actively aggregating before sampling, and many aggregates are preserved. Cores of aggregates are Fe-rich (magnetite?). Silicates include weathered lithics (larger), shards, plagioclase and, amphibole (or px?), in the proportion expected.

and dangerous. Although the new data represent much more energetic activity than has been measured well before, they nonetheless represent a relatively low eruption rate compared with the most intense episodes of the eruption. The ash eruption rate estimated above (1.5 $\mathrm{x}$ $10^{6} \mathrm{t} / \mathrm{d}$ ) is slightly higher than those of the weak eruptions of February 1976 which were sampled by Hobbs et al. [1977]. By contrast, the eruption rates during the peak of the 1976 eruption were probably in the range of $10^{8} \mathrm{t} / \mathrm{d}$ or more, based on the volume $\left(0.186 \mathrm{~km}^{3}\right.$ DRE, [Kienle and Swanson, 1985]) and its duration of about 3 days. The March-April 1986 eruption may have involved similar eruption rates, although it seems from the descriptions and data available that it was somewhat smaller in volume. The value $10^{8} \mathrm{t} / \mathrm{d}$ is about 50 times the rate estimated on April 3, 1986, so it is clear that we need to consider how to scale the eruption cloud parameters by a large factor. Specifically we must evaluate whether the proportions of materials we measured are likely to apply at the peak of the eruption.

Table 8 compares plume characteristics at different stages of activity at Augustine, based on the eruption
GEOPOTENTIAL (GPM) AT $1000 \mathrm{MB}$ FOR 4/4/B6 0 GMT

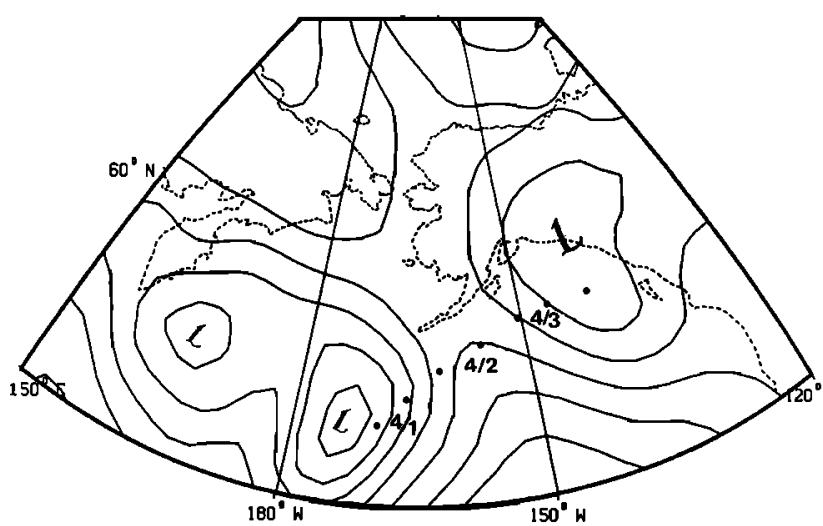

GEOPOTENTIAL (GPM) AT $500 \mathrm{MB} \quad \mathrm{FOR}$ 4/ 4/86 0 GMT

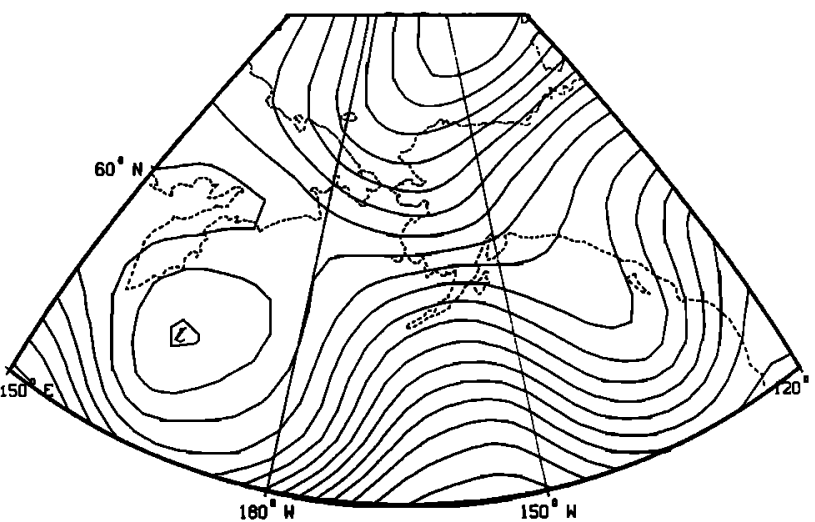

Fig. 6. Geopotential maps at $1000 \mathrm{mbar}$ and 500 mbar for 1500 AST, April 3, 1986. 

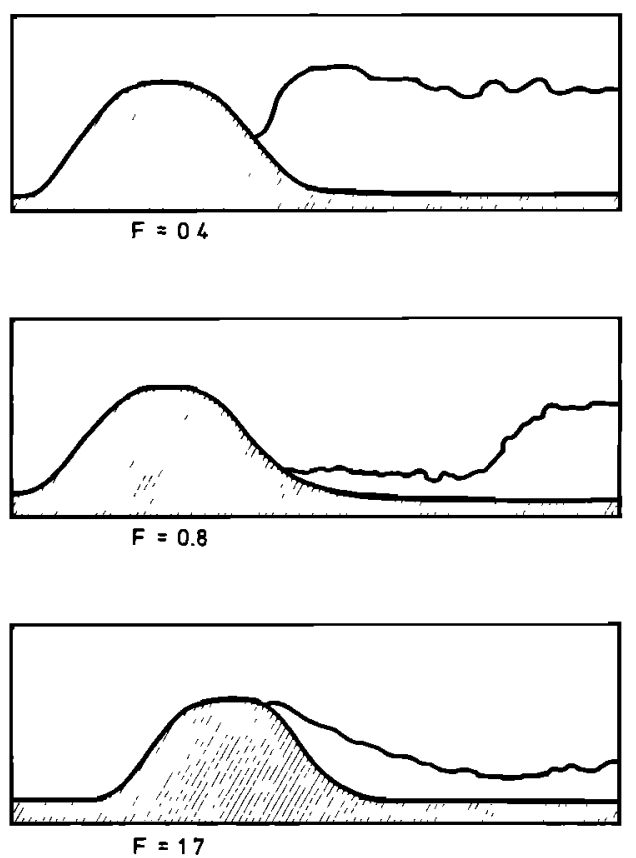

Fig. 7. Tracings from shadowgraphs of stratified flow in a water channel. The cross-hatched area is a cylindrically symmetrical obstacle. The irregular area downwind of the obstacle is a disturbed wake flow [from Hunt et al., 1978]. $F$ is Froude number.

cloud samples, bulk ash analyses, and Cospec results. It includes estimates of some proportions of ash and gaseous components during the most explosive activity. To derive the final column of the table, three assumptions labeled and discussed below were made.

The gas/aerosol ratios for $\mathrm{S}$ and $\mathrm{Cl}$ that we measured are similar to results for other volcanoes [Lazrus et al., 1979; Kotra et al., 1983; Stoiber, et al., 1987]. The available data thus suggest that in eruption clouds and plumes, aerosol $\mathrm{S}$ and $\mathrm{Cl}$ make up about $1-10 \%$ and $5-20 \%$ of the $\mathrm{S}$ and $\mathrm{Cl}$ gas flux, respectively.

Assumotion 1: We assume that these percentages are also representative of intense eruptive activity. If this is true, we can use ash leachate data to constrain the amounts of gas in eruption clouds when we lack direct measurements, by using a factor multiplier. During its open vent, fuming state, the volcano is not emitting ash but has a concentrated plume of $\mathrm{H}_{2} \mathrm{O}, \mathrm{SO}_{2}, \mathrm{HCl}, \mathrm{HF}$, and other gases, with a low $\mathrm{S} / \mathrm{Cl}$ ratio $(<0.1)$. During low-level activity, such as on April 3, the ash emission rate is moderate and the concentrations of $\mathrm{SO}_{2}$ and $\mathrm{HCl}$ together amount to about $2 \%$ of the mass of ash being emitted.

Direct visual observation of the height of the eruption cloud shows that the intensity of activity we measured on April 3 was much lower than the peak activity between March 27 and April 2. In order to scale our measured data to the maximum eruption rates, seismic data were consulted. Magnitudes of explosion earthquakes during the 9 days varied over more than an order of magnitude (Figure 9), and the detail of that record is better defined than actual observations of the eruption column. The most intense explosions were about 50 times more energetic based on the magnitude of explosion earthquakes.

Assumption 2: We used a factor of 50 to scale up the ash flux from "low level" to "eruption peak" (Table 8). Wilson et al [1978] have shown that the column height $(\mathrm{H})$ during a pyroclastic eruption is roughly proportional to its eruption rate $(Q)$ by an equation $H=236.6 Q^{\dagger}$. An eruption rate of $7.5 \times 10^{7} \mathrm{t} / \mathrm{d}$ of ash would approximately correspond to a column height of $8-10 \mathrm{~km}$, a height observed on several occasions between March 27 and April 2 [Yount et al, 1987]. To scale the amounts of $\mathrm{S}$ and $\mathrm{Cl}$ during the peak of eruption, however, we will not use a factor of 50 because the ashes that fell at Homer, Kenai, and Anchorage contain less $\mathrm{S}$ and $\mathrm{Cl}$ than the samples acquired within the plume on April 3, and we believe that the proportions of gas to ash in the most explosive eruption clouds may be lower than the April 3 cloud.

Assumotion 3: We assume instead that during the eruptive peak the $\mathrm{SO}_{2}$ mass flux was $0.5 \%$ of the ash flux, which is a value consistent with results obtained from study of melt inclusions [Johnston, 1978], and that the $\mathrm{S}$ and $\mathrm{Cl}$ emission rate was only about 16 times the low-level rate. We estimate that $\mathrm{SO}_{2}$ and $\mathrm{HCl}$ gas make up no more than about $1 \%$ of the mass of ash released in the most explosive part of the eruption, and that the $\mathrm{S} / \mathrm{Cl}$ ratio of that mixture is $>2$.

As first pointed out by Johnston [1980], Augustine's high $\mathrm{Cl}$ releases highlight interest in quantifying the natural flux of $\mathrm{Cl}$ to the atmosphere. A central point here is whether the high $\mathrm{Cl}$ content of the magma is of deep-seated origin or whether it is somehow related to influx of seawater through an underground aquifer. The location suggests the latter possibility, as does the interpretation of seismicity by D. J. Lalla (thesis in preparation, 1980). Johnston's work showed that the high $\mathrm{Cl}$ content was recorded in melt inclusions trapped within

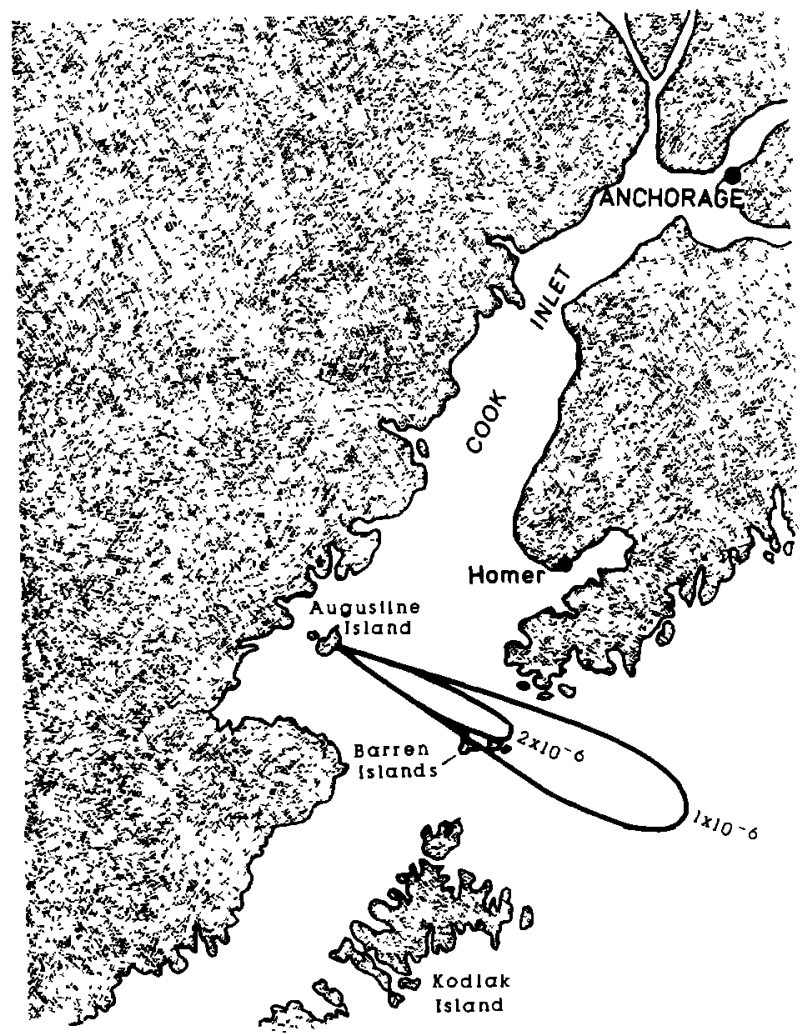

Fig. 8. Estimated concentration isopleths for $\mathrm{C}=1,2 \mathrm{x}$ $10^{-6} \mathrm{~kg} / \mathrm{m}^{3}$ of $\mathrm{SO}_{2}$ emitted from Augustine, assuming a constant emission rate of $280 \mathrm{~kg} / \mathrm{s}$ and the geopotential shown in Figure 6. Determined by plume dispersion model explained in text. 
TABLE 7. Results of Aerial Cospec Survey at Augustine Volcano July 24, 1986

\begin{tabular}{cccccc}
\hline $\begin{array}{c}\text { Traverse } \\
\text { Number }\end{array}$ & $\begin{array}{c}\text { Time, } \\
\text { UT }\end{array}$ & $\begin{array}{c}\text { Traverse } \\
\text { Elevation, } \\
\text { ft }\end{array}$ & $\begin{array}{c}\text { Plume } \\
\text { Width, } \\
\text { km }\end{array}$ & $\begin{array}{c}\text { Average, } \\
\text { ppm m }\end{array}$ & $\begin{array}{c}\text { Flux, } \\
\text { t/d }\end{array}$ \\
\hline 3 & 1252 & 500 & 5.1 & 130 & 393 \\
4 & 1257 & 500 & 5.4 & 99 & 315 \\
5 & 1304 & 500 & 7.1 & 78 & 327 \\
6 & 1310 & 500 & 5.1 & 125 & 375 \\
7 & 1317 & 500 & 6.4 & 103 & 391 \\
8 & 1324 & 500 & 6.8 & 103 & 414 \\
9 & 1331 & 500 & 6.7 & 109 & 431 \\
\hline
\end{tabular}

A11 measurements done flying perpendicular to the plume at 97-108 knots. The wind speed used in flux calculation was 5 knots. The reported winds for Anchorage (at 1135) were $240^{\circ}$ at 07 knots for $3000 \mathrm{ft}$ and $240^{\circ}$ at 09 knots for $6000 \mathrm{ft}$. The measured winds (using the Loran C) in the Augustine area were 200 at 05 knots (at 1230) for $2000 \mathrm{ft}$ and 220 at 04 knots (at 1405) for $3000 \mathrm{ft}$. The lack of turbulence during the measurements is consistent with wind speeds less than 7 knots.

phenocrysts of the dacite, showing that the $\mathrm{Cl}$ entered the system before crystallization was complete. This suggests that the $\mathrm{Cl}$ may come from a deeper source. Anderson's [1974, 1982] work demonstrated that many other convergent plate boundary volcanoes, including some rather far from the sea, also have high pre-eruption $\mathrm{Cl}$. It is important to know how general high $\mathrm{Cl}$ releases are for explosive volcanoes, because of its possible role in the atmospheric ozone degradation.

Rose et al. [1983], Sigurdsson et al. [1985] and Woods et al. [1985] have presented data allowing minimum estimates of the $\mathrm{Cl}$ release of some recent explosive eruptions. Although $\mathrm{Cl}$ releases from basaltic volcanoes are sometimes very minor [Anderson, 1974], magmas of intermediate or high silica content release much larger amounts, of ten subequal to or exceeding the $S$ releases regardless of their proximity to the sea. In view of the frequency of intermediate silica eruptions, we assert that volcanic contributions of $\mathrm{Cl}$ to the atmosphere may be of significance with respect to the world industrial production of $\mathrm{Cl}$-bearing compounds, a conclusion first suggested by Johnston [1980].

Another question raised by the high $\mathrm{Cl}$ content of the Augustine gases is the chloro- and fluorohydrocarbon releases and the releases of other halide species. We have no direct data on the amounts of these compounds, but mass action considerations suggest that such species should be much more abundant in gas mixtures rich in $\mathrm{HCl}$. Because the enrichment of halogen-bearing gases in the stratosphere is possibly related to the ozone hole phenomenon and also to greenhouse warming, we need to know the magnitude of natural releases.

The low enrichments of cations observed in the Augustine eruption materials (Figure 3 ) should be considered by those who have suggested that the occurrence of both shocked minerals and enrichments of Ir and other elements in the $K / T$ boundary materials are consistent with explosive volcanism [e.g. Carter et al.,

TABLE 8. Scaling Up Emission Rates During Eruptions, Data From St. Augustine Volcano, Alaska

\begin{tabular}{|c|c|c|c|}
\hline & uming Vent* & $\begin{array}{l}\text { Low Leve1 } \\
\text { Eruption } \dagger\end{array}$ & $\begin{array}{l}\text { Peak of } \\
\text { Eruption } \neq\end{array}$ \\
\hline $\mathrm{SO}_{2} \underset{t / d}{\mathrm{flux}}$, & 380 & 24,000 & 375,000 \\
\hline $\begin{array}{c}\mathrm{HC1} \text { flux, } \\
t / d\end{array}$ & 8,000 & 10,000 & 160,000 \\
\hline Ash flux & 0 & $1.5 \times 10^{6}$ & $7.5 \times 10^{7}$ \\
\hline $\begin{array}{l}\mathrm{SO}_{2} / \mathrm{HCl} \\
\mathrm{SO}_{2} / \mathrm{ash}, \%\end{array}$ & 0.05 & $\begin{array}{l}2.4 \\
1.5\end{array}$ & $\begin{array}{l}2.4 ? \\
0.5\end{array}$ \\
\hline S gas/aerosol & ? & 10 & 10 \\
\hline Cl gas/aerosol & $?$ & 4 & 4 \\
\hline
\end{tabular}

*Data from Ju1y 24, 1986 [Symonds et al., 1987a,b].

Tata from April 3, 1986.

ł Scaling up assumptions applied to seismic data, ash fallout and observations, and theoretical considerations (see text). 


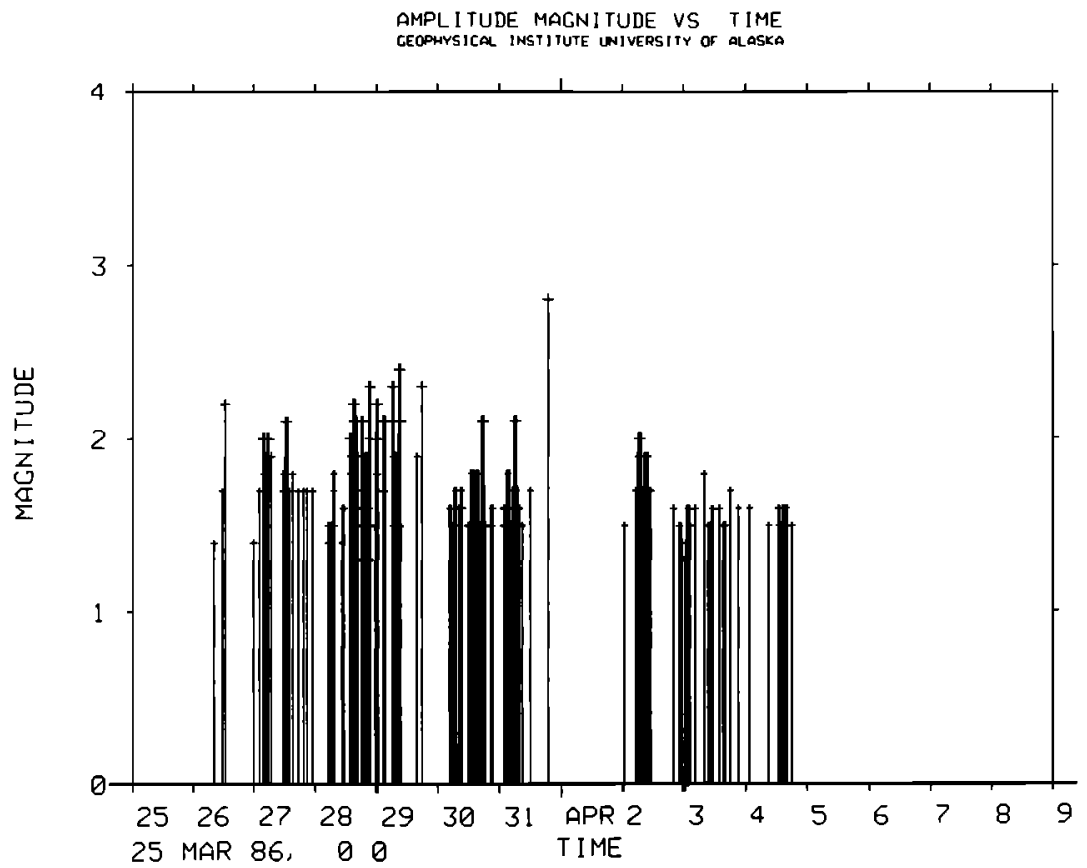

Fig. 9. Plot of explosion magnitudes as measured by seismic station OPT, $28 \mathrm{~km}$ north of Augustine (from J. Power and J. Davies, Geophysical Institute, University of Alaska, personal communication, 1987. Times are in GMT.

1986]. Even the very $\mathrm{Cl}$-rich eruptive gases of Augustine do not produce large enrichnments of cations because of the large ash volumes, which mask the gaseous component. Either low-level explosive degassing activity [Phelan et al., 1982] or effusive activity with little volcanic ash [Zoller et al., 1983] is a much better condition for highly enriched volcanic emissions than highly explosive eruptions. Thus the combination of highly dispersed ash and highly enriched volatile metals seems unlikely.

A logical extension of this study is to test our dispersion model (Figure 8) with satellite images. We know, for example, that some weather satellite images of the March 27 to April 4, 1986, period show plumes with about the same shape and extent. In the future we will attempt to calibrate the weather satellites and the TOMS/Nimbus 7 instrument, so that we can get a quantitative estimate of plume concentrations, for both ash and $\mathrm{SO}_{2}$, directly from the satellite data. We hope that this Augustine research will be the first step toward that long-term goal.

\section{Conclusions}

1. The Augustine eruption released $1.5 \times 10^{6} \mathrm{t} / \mathrm{d}$ of ash 24,000 t/d of $\mathrm{SO}_{2}$, and 10,000 t/d of $\mathrm{HCl}$ on April 3, 1986 during low-level activity. Peak eruption rates, achieved (or exceeded?) several times during the 9-day eruption, are estimated at $7.5 \times 10^{7} \mathrm{t} / \mathrm{d}$ of ash, 375,000 $\mathrm{t} / \mathrm{d}$ of $\mathrm{SO}_{2}$, and $160,000 \mathrm{t} / \mathrm{d}$ of $\mathrm{HCl}$.

2. The 1986 eruption of Augustine Volcano released proportionally large amounts of $\mathrm{Cl}$, approximately equivalent to the $S$ released and about 0.2 wt $\%$ of the magma volume. We do not know how many volcanoes release similarly high amounts of $\mathrm{Cl}$ to the atmosphere

3. The relative proportion of gases to silicates in eruption clouds decreases sharply as the intensity of activity increases, and this relationship must be quantified to enable us to accurately estimate eruption rates of gases.

4. The gas/aerosol proportions of $\mathrm{S}$ and $\mathrm{Cl}$ in the low-level Augustine eruption cloud were about 10:1 and 4:1, respectively.

5. Lee wave phenomena during eruptions or plume emissions allow constraints on dispersion models which may allow for more precise modeling. Such models are needed to calibrate satellites which detect ash and $\mathrm{SO}_{2}$ clouds to allow ash cloud movement and fallout forecasts.

Acknowledgements. Financial support for this research came from the Los Alamos National Laboratory, through the ESS-1 and INC-7 groups. Additional support was provided by the National Science Foundation through grant EAR-8420625, and the U.S. Geological Survey, Branch of Alaskan Geology. Juergen Kienle urged us to come quickly to Augustine, and we are grateful for his continued encouragement. We thank John Power and John Davies for sharing valuable seismic data with us, Betsy Yount for supplying us with preprints and photographs of her work on Augustine, and Tom Miller for logistical help. Mike Carr and Steve Self are thanked for greatly improving the manuscript.

\section{References}

Anderson, A. T., Jr., Chlorine, sulfur and water in magmas and oceans, Geol. Soc. Amer. Bull. 85, 1485-1492, 1974.

Anderson, A. T., Parental basalts in subduction zones: Implications for continental evolution, J. Geophys. Res. 87, 7047-7060, 1982.

Berresheim, H., and W. Jaeschke, The contribution of volcanoes to the global atmospheric sulfur budget, $L$ Geophys. Res.. 88, 3732-3740, 1983.

Carter, N. L., C. B. Officer, C. A. Chesner, and W. I. Rose, Dynamic deformation of volcanic ejecta from the Toba Caldera: Possible relevance to Cretaceous/Tertiary boundary phenomena, Geology, 14, 380-383, 1986.

Casadevall, T. J., D. A. Johnston, D. M. Harris, W. I. 
Rose, L. L. Malinconico, R. E. Stoiber, T. J. Bornhorst, and S. N. Williams, SO2 emission rates at Mount St. Helens: March 29 to November 1, 1980, U.S. Geol. Surv. Bull. 1250, 193-200, 1981.

Casadevall, T. J., W. I. Rose, W. Fuller, W. Hunt, M. Hart, J. Moyers, D. Woods, R. Chuan, and J. Friend, Sulfur dioxide and particles in volcanic plumes from Poas, Arenal and Colima volcanoes, Costa Rica and Mexico: February 1982, J. Geophys. Res. 89, 9633-9641, 1984.

Chuan, R. L., Rapid measurement of particulate size distribution in the atmosphere, in Fine Particles edited by B. Y. H. Liu, Academic, Orlando, Fla., pp. $763-775,1975$.

Chuan, R. L., J. Palais, W. I. Rose, and P. R. Kyle, Particle sizes and fluxes of the Mt. Erebus volcanic plume, J. Atmos. Chem. 4, 467-477. 1986.

Devine, J. D., H. Sigurdsson, A. N. Davis, and S. Self, Estimates of sulphur and chlorine yield to the atmosphere from volcanic eruptions and potential climatic effects, J. Geophys. Res.. 89, 6309-6325, 1984.

Gerlach, T. M., and T. J. Casadevall, Fumarole emissions at Mount St. Helens Volcano June 1980 -October 1981: Degassing of a magma-hydrothermal system, I. Volcanol. Geotherm. Res. 28, 141-160, 1986.

Greenland, L. P., W. I. Rose, and J. B. Stokes, An estimate of gas emissions and magmatic gas content from Kilauea Volcano, Geochim. Cosmochim. Acta. 49, 125-129, 1985

Harris, D. M., M. Sato, T. J. Casadevalt, W. I. Rose, and T. J. Bornhorst, Emission rates of $\mathrm{CO}_{2}$ at Mount St. Helens Volcano, U.S. Geol. Surv. Bull. 1250, 201-208, 1981.

Heffter, J. L., Variation of horizontal diffusion parameters with time for travel periods of one hour or longer, $J$. Appl. Meteorol. 4, 153-156, 1965.

Hobbs, P. V., L. F. Radke, and J. L. Stith, Eruptions of the St. Augustine Volcano: airborne measurements and observations, Science, 195, 871-873, 1977.

Hobbs, P. V., L. F. Radke, M. W. Eltgroth and D. A. Hegg, Airborne studies of the emissions of Mount St. Helens, Science, 211, 816, 1981 .

Hunt, J. C. R., W. H. Snyder, and R. E. Lawson, Jr., Flow structure and turbulent diffusion around a three-dimensional hill: fluid modeling study on effects of stratification, 1. Flow structure, EPA-600/4-78-041, U. S. Environ. Prot. Agency, Research Triangle Park, N.C., 1978.

Johnston, D. A., Volatiles, magma mixing and the mechanism of eruption of Augustine Volcano, Alaska, Ph.D. thesis, 177 pp., Univ. of Wash., Seattle, 1978.

Johnston, D. A., Volcanic contribution of chlorine to the stratosphere--More significant to ozone than previously estimated, Science, 209 (4455), 491-493, 1980.

Kienle, J., Augustine volcano: awake again? EOS Trans. AGU. 67 580-582 (8 April 1986), 1986.

Kienle, J., and G. E. Shaw, Plume dynamics, thermal energy and long dis-tance transport of vulcanian eruption clouds from Augustine Volcano, Alaska, J. Volcanol, Geotherm. Res. 6, 139-164, 1979.

Kienle, Juergen, and S. E. Swanson, Volcanic hazards from future eruptions of Augustine Volcano, Alaska, Geophysical Institute Report UAG R-275, 122 p., Fairbanks, Univ. of Alaska, 1985.

Kotra, J. P., D. L. Finnegan, and W. H. Zoller, El Chichón: composition of plume gases and particles. Science. 222, 1081-1021, 1983.

Krueger, A. J., Sighting of the El Chichon sulfur dioxide clouds with the Nimbus 7 total ozone mapping spectrometer, Science. 220, 1377-1379, 1983.
Krueger, A. J., Detection of volcanic eruptions from space by their sulfur dioxide clouds, paper presented at the 23rd Aerospace Science Meeting, Am. Inst. of Aeronautics ans Astronautics, Reno, 1985.

Lazrus, A. L., R. D. Cadle, B. W. Gandrud, and J. P. Greenberg, Sulfur and halogen chemistry of the stratosphere and of volcanic eruption plumes, $L$ Geophys. Res. 84, C12, 7869-7875, 1979.

Leavitt, S. W., Annual volcanic carbon dioxide emission: an estimate from eruption chronologies, Environ. Geol. $4,15-21,1982$.

Lepel, E. A., K. M. Stefansson, and W. H. Zoller, The enrichment of volatile elements in the atmosphere by volcanic activity: Augustine Volcano, 1976, L Geophys. Res. 83, 6213-6220, 1978.

Long, R. E., Some aspects of the flow of stratified fluids. III. Continuous density gradients, Tellus. 7, 342-357, 1955.

Lyra, G., Theorie der stationaren Leewellenstrōmung in frien Atmosphăre, Z. Angew, Math Mech.. 23, 1943.

Matson, M., The 1982 El Chichón Volcano eruptions - a satellite perspective, J. Volcanol. Geotherm. Res.. 23, $1-10,1984$.

Millán, M. M., A. J. Gallant, C. S. Yong, and F. Fauaki, Observation of Mt. St. Helens volcano $\mathrm{SO}_{2}$ eruption cloud of May 18, 1980 over southern Ontario, Atmos. Environ. 19, 255-263, 1985.

Phelan, J. M., D. L. Finnegan, D. S. Phelan, J. M., D. L. Finnegan, D. S. Ballantine, W. H. Zoller, M. A. Hart, and J. L. Moyers, Airborne aerosol measurements in the quiescent plume of Mount St. Helens: September 1980, Geophys. Res. Lett. 9, 1093-1096, 1982.

Queney, P., The problem of air flow over mountains: a summary of theoretical studies, Bull. Amer. Meteorol. Soc. 29, 16-23, 1948.

Rose, W. I., A volcanologist's perspective of the interaction of aircraft and eruption clouds, AlAA Journal. 25, 52-58, 1986.

Rose, W. I., R. L. Chuan, R. D. Cadle, and D. C. Woods, Small particles in volcanic eruption clouds, Am. J. Sci. 280, 671-696, 1980.

Rose, W. I., R. L. Chuan, and D. C. Woods, Small particles in plumes of Mount St. Helens, J. Geophys. Res. 87, 4956-4962, 1982.

Rose, W. I., R. L. Wunderman, M. F. Hoffman, and L. Gale, A volcanologist's review of atmospheric hazards of volcanic activity: Fuego and Mount St. Helens, J. Volcanol. Geoth. Res. 17, 133-157, 1983.

Rose, W. I., R. L. Chuan, W. F. Giggenbach, P. R. Kyle, and R. B. Symonds, Rate of sulfur dioxide and particle emission from White Island Volcano, New Zealand and an estimate of the total flux of major gaseous species, Bull. Volcanol.. 48, 181-187, 1986.

Rose, W. I., R. E. Stoiber, and L. L. Malinconico, Eruptive gas compositions and fluxes of explosive volcanoes: Problems, techniques and initial data, in Orogenic Andesites and Related Rocks, edited by R. S. Thorpe, pp. 669-676, John Wiley and Sons, New York, 1981

Scorer, R. S., The theory of waves in the lee of mountains, Q. J.R. Meteorol, Soc. 75, 41-56, 1959.

Stith, J. L., P. V. Hobbs, and L. F. Radke, Observations of a nuée ardente from St. Augustine Volcano, Geophys. Res. Lett. 4, 259-262, 1977.

Stoiber, R. E., and A. Jepsen, Sulfur dioxide contributions to the atmosphere by volcanoes, Science. 182, 577-578, 1974.

Stoiber, R. E., and W. I. Rose, Fumarole incrustations at active Central American volcanoes, Geochim. Cosmochim. Acta. 38, 485-516, 1974.

Stoiber, R. E., S. N. Williams, and B. Huebert, Annual 
contributions of sulfur dioxide to the atmosphere by volcanoes, J. Yolcanol. Geotherm. Res. 33, 1987.

Stoiber, R. E., S. N. Williams, and B. J. Huebert, Sulfur and halogen gases at Masaya Caldera Complex, Nicaragua: Total flux and variations with time, $\mathbf{J}$ Geophys. Res. 91, 12,215-12,231, 1986.

Symonds, R. B., W. I. Rose, Jr., M. H. Reed, Paul Briggs, and T. M. Gerlach, The speciation and fluxes of gases from Augustine Volcano, Alaska: a system rich in halides and transition metals, paper presented at Hawaiian Volcano Observatory Diamond Jubilee, Hilo, Hawaii, Jan., 1987a.

Symonds, R. B., W. I. Rose, M. H. Reed, F. E. Lichte, and D. L. Finnegan, Volatilization, transport and sublimation of metallic and non-metallic elements in high temperature gases at Merapi Volcano, Indonesia, Geochim. Cosmochim. Acta. 51, 2083-2101, 1987b.

Wilson, L., R. S. J. Sparks, T. C. Huang, and N. D. Watkins, The control of column heights by eruption energetics and dynamics, L. Geophys. Res.. 83, 1829-1836, 1978.

Woods, D. C., R. L. Chuan, and W. I. Rose, Halite particles injected into the stratosphere by the $1982 \mathrm{El}$ Chichón eruption,Science. 230, 170-172, 1985.
Yount, M. E., T. P. Miller, and B. M. Gable, The 1986 eruptions of Augustine Volcano, Alaska: Hazards and Effects, U. S. Geol. Surv. Alaska Accomplishment Circ. 998, 4-14, 1987.

Zoller, W. H., J. R. Parrington, and J. M. P. Kotra, Iridium enrichment in airborne particles from Kilauea Volcano: January 1983, Science. 222, 1118-1121, 1983.

S. Barr, G. Heiken and K. Wohletz, Los Alamos National Laboratory, Los Alamos, NM 87545.

R. L. Chuan, Brunswick Corporation, Costa Mesa, CA 92676.

D. Eppler, SAIC, Las Vegas, NV 89109.

T. Miller, Chemistry Department, University of Washington, Seattle, WA 98195.

W. I. Rose and R. B. Symonds, Michigan Technological University, Houghton, MI 49931.

(Received May 18, 1987;

revised November 2, 1987; accepted December 22, 1987.) 